\title{
The Comparatively Proteomic Analysis in Response to Cold Stress in Cassava Plantlets
}

\author{
Feifei $\mathrm{An}^{1} \cdot$ Genghu $\mathrm{Li}^{1} \cdot$ Qing X. $\mathrm{Li}^{2} \cdot$ Kaimian $\mathrm{Li}^{1} \cdot$ Luiz J. C. B. Carvalho ${ }^{3}$. \\ Wenjun $\mathrm{Ou}^{1} \cdot$ Songbi Chen ${ }^{1}$
}

Published online: 6 May 2016

(C) The Author(s) 2016. This article is published with open access at Springerlink.com

\begin{abstract}
Cassava (Manihot esculenta Crantz) is a tropical root crop and sensitive to low temperature. However, it is poorly to know how cassava can modify its metabolism and growth to adapt to cold stress. An investigation aimed at a better understanding of cold-tolerant mechanism of cassava plantlets was carried out with the approaches of physiology and proteomics in the present study. The principal component analysis of seven physiological characteristics showed that electrolyte leakage (EL), chlorophyll content, and malondialdehyde (MDA) may be the most important physiological indexes for determining cold-resistant abilities of cassava. The genome-wide proteomic analysis showed that 20 differential proteins had the same patterns in the apical expanded leaves of cassava SC8 and Col1046. They were mainly related to photosynthesis, carbon metabolism and energy metabolism, defense, protein synthesis, amino acid metabolism, signal transduction, structure, detoxifying and antioxidant, chaperones, and DNA-binding proteins, in which $40 \%$
\end{abstract}

Electronic supplementary material The online version of this article (doi:10.1007/s11105-016-0987-x) contains supplementary material, which is available to authorized users.

Kaimian Li

likaimian@sohu.com

Songbi Chen

songbichen@yahoo.com

1 Tropical Crops Genetic Resources Institute, Chinese Academy of Tropical Agricultural Sciences/Key Laboratory of Ministry of Agriculture for Germplasm Resources Conservation and Utilization of Cassava, Danzhou 571737, China

2 Department of Molecular Biosciences and Bioengineering, University of Hawaii at Manoa, Manoa, HI, USA

3 Genetic Resources and Biotechnology, Embrapa, Brazil were related with photosynthesis. The remarkable variation in photosynthetic activity and expression level of peroxiredoxin is closely linked with expression levels of proteomic profiles. Moreover, analysis of differentially expressed proteins under cold stress is an important step toward further elucidation of mechanisms of cold stress resistance.

Keywords Cassava plantlets · Comparative proteome $\cdot$ Cold stress $\cdot$ Differential proteins

$\begin{array}{ll}\begin{array}{l}\text { Abbreviations } \\ \text { APX }\end{array} & \begin{array}{l}\text { Ascorbate peroxidase } \\ \text { Rubulose-1,5-bisphosphate } \\ \text { Rubisco }\end{array} \\ \text { carboxylase } \\ \text { ATP } & \begin{array}{l}\text { Adenosine-5'-triphosphate } \\ \text { Electrolyte leakage }\end{array} \\ \text { EL } & \text { Glutathione S-transferase } \\ \text { GST } & \text { Heat shock protein } \\ \text { HSP } & \text { Matrix-assisted laser } \\ \text { MALDI-TOF-TOF-MS } & \text { desorption ionization-time } \\ & \text { of flight mass } \\ & \text { spectrometry } \\ & \text { Malondialdehyde } \\ \text { MDA } & \text { Nitro blue tetrazolium } \\ \text { NBT } & \text { Polyacrylamide gel } \\ \text { PAGE } & \text { electrophoresis } \\ & \text { Peroxidase } \\ \text { POD } & \text { Rubisco activase } \\ \text { RCA } & \text { Reactive oxygen species } \\ \text { ROS } & \text { Sodium dodecyl sulfate } \\ \text { SDS } & \text { Superoxide dismutase } \\ \text { SOD } & \text { Thiobarbituric acid } \\ \text { TBA } & \end{array}$




\section{Introduction}

Being sessile, plants mainly depend on physiological and metabolic adaptations to obtain the phenotypic flexibility required to withstand the adverse biotic and abiotic growth conditions (Sergeant and Renaut 2010), such as drought, low temperature, and salinity. Low temperature has a great impact on plant productivity, mostly because it significantly alters plant metabolism and physiology (Timperio et al. 2008). Cassava (Manihot esculenta Crantz) is a staple food for more than 800 million people in the world (Lebot 2008). As a tropical root crop, cassava is sensitive to low temperature (Huang et al. 2005). It can modify its metabolism and growth to adapt to cold stress by reprogramming gene expression to increase the ability to withstand oxidative stress and synthesis of coldinduced proteins during cold acclimation (Kjellsen et al. 2010).

Plants have evolved elaborating mechanisms that allow them to perceive the external signals and to manifest adaptive responses with appropriate physiological changes (Hashimoto and Komatsu 2007). Under cold stress, the plasma membrane undergoes phase transition, from the liquid crystalline to a rigid gel phase (Lyons 1973). The capacity for $\mathrm{O}_{2}$ uptake and delivery was reduced, and excess $\mathrm{O}_{2}$ in the metabolic process was converted into reactive oxygen species (ROS) (Van Breusegem et al. 1999). At high concentration, ROS cause damage to cell structures and biomolecules; thus, plant cells trigger antioxidant networks to scavenge excessively produced ROS (Koehler et al. 2012; Raimbault et al. 2011; Haghjou et al. 2009). In addition, the compatible osmolytes, such as proline, betaine, and soluble sugars, were increased under cold stress (Hare et al. 1998; Grimaud et al. 2013). The prolonged exposure to low temperature will also decrease the chlorophyll content of plants (Liu et al. 2012; Zhou et al. 2012a, b). Response to cold stress for $4 \mathrm{~h}$ in cassava showed that MDA concentrations rapidly decreased to $50 \%$, but proline dramatically increased and sugar content remained unchanged, but obviously increased after $24 \mathrm{~h}$ (An et al. 2012).

Using plant transformation methods, many plants could be improved their abilities to adapt the cold stresses, such as transforming AtproDH and $C B F 3$ genes in Arabidopsis thaliana (Nanjo et al. 1999; Gilmour et al. 1998), ZmMPK4 and MfGolS1 genes in tobacco (Zhou et al. 2012a, b; Zhuo et al. 2013), RdreB1BI gene in strawberries (Gu et al. 2013), AtDREB1A/CBF3 gene in Lolium perenne (Li et al. 2011), and $P 5 C S$ gene in larch (Gleeson et al. 2005). With the recent completion of the cassava genome sequence, many genes in cassava associated with cold tolerance were identified (Vergnolle et al. 2005; Rabbani et al. 2003; Wang et al. 2014). Coupled expression of $\mathrm{Cu} / \mathrm{Zn}$-superoxide dismutase (SOD) and catalase was presented in cassava by transforming both $\mathrm{Cu} / \mathrm{Zn}$-SOD and $C A T$ genes to improve tolerance against cold and drought stresses (Xu et al. 2013). Transformation of
$C B F 3$ gene in cassava could enhance the cold tolerance (Liu et al. 2011), and the expression of native cytosolic transformed $S O D$ and ascorbate peroxidase $(A P X)$ genes simultaneously activated the antioxidative defense mechanisms via cyclic ROS scavenging, thereby improved cassava tolerance to cold stress (Xu et al. 2014). At RNA level, a total of 508 transcripts in cassava were identified as early cold-induced genes of which 319 sequences had functional descriptions aligned with Arabidopsis proteins (An et al. 2012).

The whole genome and transcriptome may provide comprehensive information about the physiological state of cassava plant and its organisms in a particular condition; however, the levels of global transcripts are not strictly correlated to the levels of the translated proteins (Ideker et al. 2001; Hajduch et al. 2010). In addition, many crucial post-translational modifications may not be screened by transcript analysis (Balbuena et al. 2011). Proteomic analysis has the potential to provide a broad view of plant responses to stress at the level of proteins (Lehesranta et al. 2005). Proteome analyses of cold responses have been carried out in different plant organisms, such as Arabidopsis (Amme et al. 2006; Fanucchi et al. 2012), wheat (Rinalducci et al. 2012), rice (Neilson et al. 2011; Cui et al. 2005), pea (Dumont et al. 2011), strawberry (Gu et al. 2013), sunflower (Balbuena et al. 2011), potato (Folgado et al. 2013), tomato (Sanchez-Bel et al. 2012), and soybean (Swigonska and Weidner 2013). However, little is known regarding the effect of cold treatment on the cassava global protein networks that underlie the key physiological processes (Sheffield et al. 2006; Li et al. 2010; Carvalho et al. 2012; An et al. 2014).

In this study, physiological and biochemical characteristics of apical shoots from cassava subjected to low temperature were analyzed. The changes of proteome pattern were studied with 2-DE in combination with MALDI-TOF-MS/MS. All differentially expressed proteins were clustered into cohesive groups based on their biological functions. The network of protein-protein was established to describe the protein interaction against stresses. Our data would be useful to further elucidate the mechanisms of cassava tolerance to cold stress and provide a new clue to cassava breeding.

\section{Materials and Methods}

\section{Plant Material, Growth Condition, and Cold Treatments}

In vitro plantlets of cassava cultivars SC8 and Col1046 were grown at $25{ }^{\circ} \mathrm{C}$ under a $16-\mathrm{h}$ photoperiod $(100$ $120 \mu \mathrm{mol} \mathrm{m} \mathrm{m}^{-2} \mathrm{~s}^{-1}$ ) for 40 days in tissue culture room. Plantlets with a uniform growth were transferred to a chamber at $25{ }^{\circ} \mathrm{C}$ under a $16-\mathrm{h}$ photoperiod for 1 day, and then, the chamber temperature was dropped from 25 to $5{ }^{\circ} \mathrm{C}$ by $0.03{ }^{\circ} \mathrm{C} / \mathrm{min}$ for cold treatment under weak light 
(approximately $54 \mu \mathrm{mol} \mathrm{m} \mathrm{m}^{-2} \mathrm{~s}^{-1}$ ). The apical expanded leaves exposed to $5^{\circ} \mathrm{C}$ for $0,3,7,10$, and 15 days were harvested and then frozen in liquid nitrogen and held at $-80^{\circ} \mathrm{C}$. Zero day was used as control. Three biological replicates were conducted in the present study.

\section{Physiological Analyses of Cold-Treated Cassava Plants}

To analyze the physiological changes of cassava under cold treatment, chlorophyll content, electrolyte leakage (EL), free proline content, malondialdehyde (MDA) content, and soluble sugar content were measured for cassava cultivars SC8 and Col1046. Chlorophyll was isolated from the apical expanded leaves according to the procedure of $\mathrm{Hu}$ et al. (2005). Chlorophyll content was calculated as described by Porra et al. (1989). EL was measured as described by Cao et al. (2007) with minor modifications. Proline content was measured according to the sulfosalicylic acid-acid ninhydrin method (Bates et al. 1973) with slight modifications. The MDA content was determined by the thiobarbituric acid (TBA) reaction with minor modifications (Dhindsa et al. 1981). Soluble sugars were extracted from the leaf tissues which were treated by cold stress according to the procedure of An et al. (2012).

\section{Detection of SOD and POD Activities}

The fully apical expanded leaves ( $1 \mathrm{~g}$ ) in cassava cultivars SC8 and Col1046 were homogenized in $5 \mathrm{~mL}$ of $10 \mathrm{mM}$ potassium phosphate buffer $(\mathrm{pH} 7.0)$ containing $4 \%(\mathrm{w} / \mathrm{v})$ polyvinylpyrrolidone. The homogenate was centrifuged at $10,000 \mathrm{rpm}$ for $15 \mathrm{~min}$, and then, the supernatant was used as the enzyme extract. All steps were carried out at $4{ }^{\circ} \mathrm{C}$. SOD activity assay was based on the method described by Beaucham and Fridovic (1971), which measures the inhibition of the photochemical reduction of nitro blue tetrazolium (NBT) at $560 \mathrm{~nm}$. Three milliliters of reaction mixture contained $50 \mathrm{mM}$ phosphate buffer ( $\mathrm{pH} 7.8), 0.1 \mathrm{mM}$ EDTA, $13 \mathrm{mM}$ methionine, $75 \mu \mathrm{M}$ NBT, $16.7 \mu \mathrm{M}$ riboflavin, and $300 \mu \mathrm{L}$ of enzyme extract. Peroxidase (POD) activity assay was based on the method described by QuintanillaGuerrero et al. (2008).

\section{Recovery of Plant Material After Cold Treatments}

In vitro plants of cassava cultivars (SC8 and Col1046) treated at $5{ }^{\circ} \mathrm{C}$ for 15 days were used as the materials for recovery experiment. The chamber temperature was increased from 5 to $25{ }^{\circ} \mathrm{C}$ by $0.03{ }^{\circ} \mathrm{C} / \mathrm{min}$ with a 16 -h photoperiod $(100-$ $120 \mu \mathrm{mol} \mathrm{m}{ }^{-2} \mathrm{~s}^{-1}$ ).
Protein Extraction, 2-DE Separation, and Protein Identification

Proteins from the apical expanded leaves of SC8 and Col1046 plantlets exposed to $5{ }^{\circ} \mathrm{C}$ for 10 days were extracted with phenol according to Chen et al. (2009). Plantlets of two genotypes grown in tissue culture room were used as the control. 2DE protein separation was conducted as previously described in An et al. (2014). Three independent biological replications were carried out in the present study. Gel matching for protein quantification was performed by Delta2D software (Decodon GmbH, Greifswald, Germany), and spot pairs were confirmed visually. The significance of differences was determined by Scheffe's test at $P<0.05$. The abundance of each protein spot was estimated by the percentage volume ( $\%$ vol). Tryptic ingel digestion and protein identification were performed by the methods reported by An et al. (2014).

\section{Generation of Protein Interaction Networks}

The differential expressed proteins identified from cassava cultivars SC8 and Col1046 were used to generate a wider protein interaction map by employing a Pathway Studio software program (www.ariadnegenomics.com) (Chen et al. 2009) and KEGG pathway software (http://www.genome.jp/ kegg/pathway.html).

\section{Chlorophyll Fluorescence Measurement}

The effective PS II quantum yield ( $\Phi$ PSII) of SC8 and Col1046 leaves under cold stress for 10 days was carried out with the Maxi-version of the Imaging-PAM and the software Imaging WIN version 2.39 (both Heinz Walz GmbH, Effeltrich, Germany) according to Oxborough (2004). Cassava leaves exposed to room temperature were used as the control. An integrated CCD camera enables view and records highly resolved digital images of the emitted fluorescence, and the total imaging area was $10 \times 13 \mathrm{~cm}$. Plants were adjusted in the dark for $20 \mathrm{~min}$ prior to measurement, and a detached leaf with was clamped onto the holder. For each variant, at least three individual plants were used.

\section{Western Blot Analyses}

Leaves of SC8 and Col1046 under cold stress for 10 days were collected for Western blot analysis. The protein extraction and Western blot were performed according to An et al. (2014). Proteins were detected by immunostaining with antiRubisco polyclonal antibody (AS07218) and antiperoxiredoxin antibody (AS05093) from Agrisera. Western blots were developed according to the method of NBT/BCIP from Roche (11681451001). 


\section{Statistical Analyses}

All data are represented as means \pm SE from three independent experiments with three replications. Statistical analysis was conducted using ANOVA, which was performed by using SPSS 17.0 to Duncan's tests. A value of $P<0.05$ was considered a statistically significant difference.

\section{Results}

\section{Phenotypic and Physiological Changes with Cold Treatment of Cassava}

Compared with in vitro plantlets of cassava cultivars SC8 and Col1046, with vigorous apical buds and fully expanded leaves, in room temperature (Fig. $1(\mathrm{a} 1, \mathrm{~b} 1)$ ), the leaves of cassava plantlets exposed to $5^{\circ} \mathrm{C}$ for 3 days displayed dehydration and wilting (Fig. 1 (a2, b2)). The phenotypic damages in both genotypes exposed to $5^{\circ} \mathrm{C}$ from 7 to 15 days (Fig. 1 (a3-5, b3-5)) showed softening and downward bending of the petioles, loss of strength in the immature stems, and more severe wilting leaves. Especially, the cold treatment caused cassava plantlets of genotype Col1046 more dehydration and wilting than SC8 (Fig. 1 (a2-5, b2-5)). However, the cold-treated plantlets of SC8 (Fig. 1 (a5)) and Col1046 (Fig. 1 (b5)) were transferred into room temperature for 2 months, as shown in Fig. 1c, d; they were recovered, suggesting that cassava phenotypic changes caused by cold treatment were reversible.

Cold stress also leads to obviously physiological changes in cassava. As an important element in photosynthesis, chlorophyll plays a key role in the absorption and conversion of light energy (Wettstein et al. 1995). Chlorophyll a content of SC8 and Col1046 exposed to $5{ }^{\circ} \mathrm{C}$ for 7 days did not change and showed a slow decrease from 10 to 15 days under cold stress. On the contrary, the content of chlorophyll b of both cassava genotypes decreased rapidly. The decrease levels of chlorophyll $\mathrm{a}$ and $\mathrm{b}$ contents in Col1046 were more than SC8 (Fig. 2a, b). EL and MDA content of SC8 and Col1046 were significantly enhanced with the extension of the cold stress time (Fig. 2c, d). The results showed that the increased levels of EL and MDA content in Col1046 were more than SC8, suggesting that cell membrane of Col1046 was more sensitive to continuously low temperature than SC8 (Fig. 2c). The significant effects of low temperature on MDA in Col1046 occurred at the exposure to $5^{\circ} \mathrm{C}$ from 10 to 15 days (Fig. $2 \mathrm{~d}$ ). The contents of free proline and soluble sugar in two
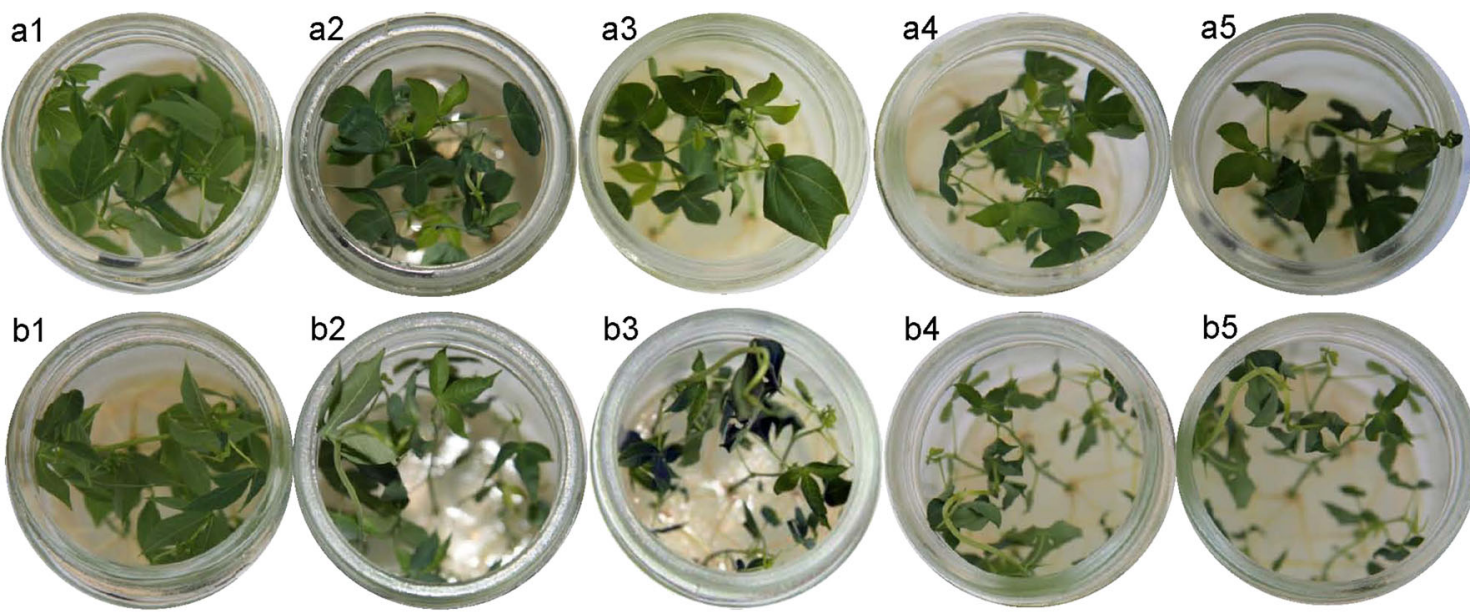

b2
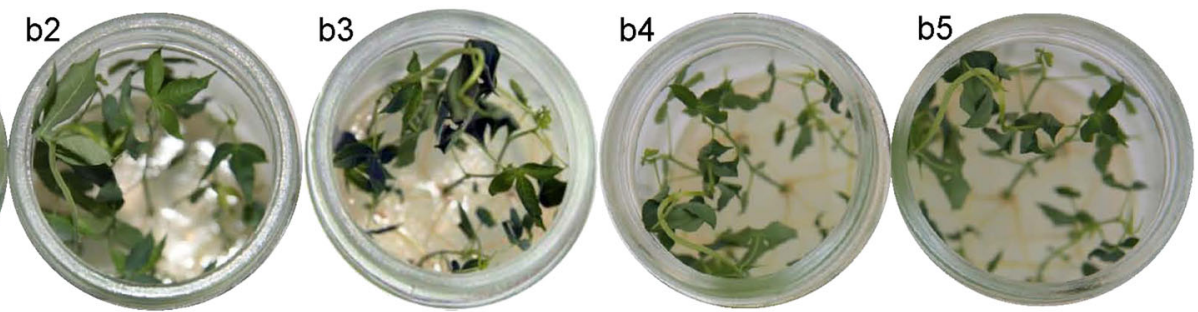

C

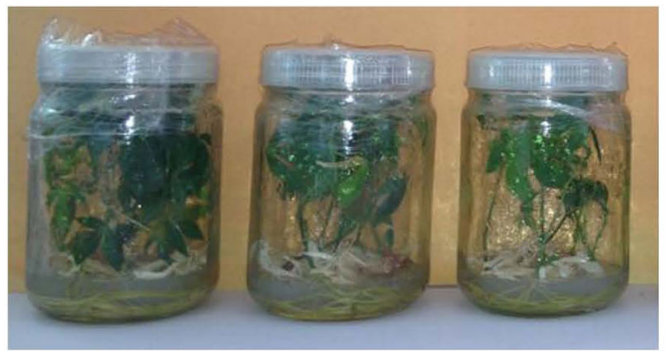

d

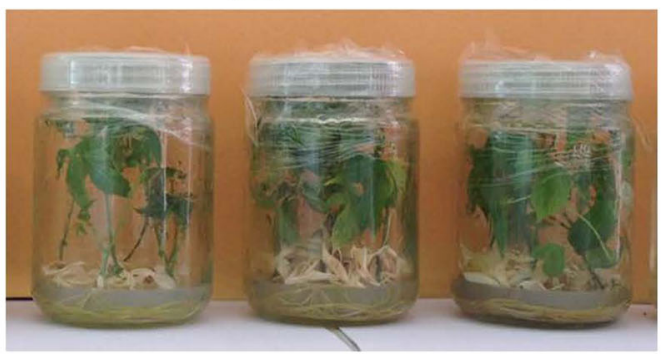

Fig. 1 Phenotypic changes in cold-stressed cassava and recovery after cold stress. a1-5, 40-day-old SC8 subjected to $5{ }^{\circ} \mathrm{C}$ for $0,3,7,10$, and 15 days in a chamber under light showing phenotypic changes, respectively; $b 1-5,40$-day-old Col1046 subjected to $5{ }^{\circ} \mathrm{C}$ for $0,3,7$, 10 , and 15 days in a chamber under light showing phenotypic changes,

respectively. c Cassava SC8 plantlets exposed to $5{ }^{\circ} \mathrm{C}$ for 15 days were moved to room temperature for 2 months. d Cassava Col1046 plantlets exposed to $5{ }^{\circ} \mathrm{C}$ for 15 days were moved to room temperature for 2 months 
Fig. 2 Contents of chlorophyll, $\mathrm{EL}$, and MDA in cold-stressed cassava apical expanded leaves. Chlorophyll a contents (a), chlorophyll b contents (b), electrolyte leakage (c), and MDA (d) in SC8 and Col1046 apical leaves exposed to $5{ }^{\circ} \mathrm{C}$ for $0,3,7$, 10 , and 15 days. The mean values are calculated from three biological replicates; the error bars represent the standard error of the mean
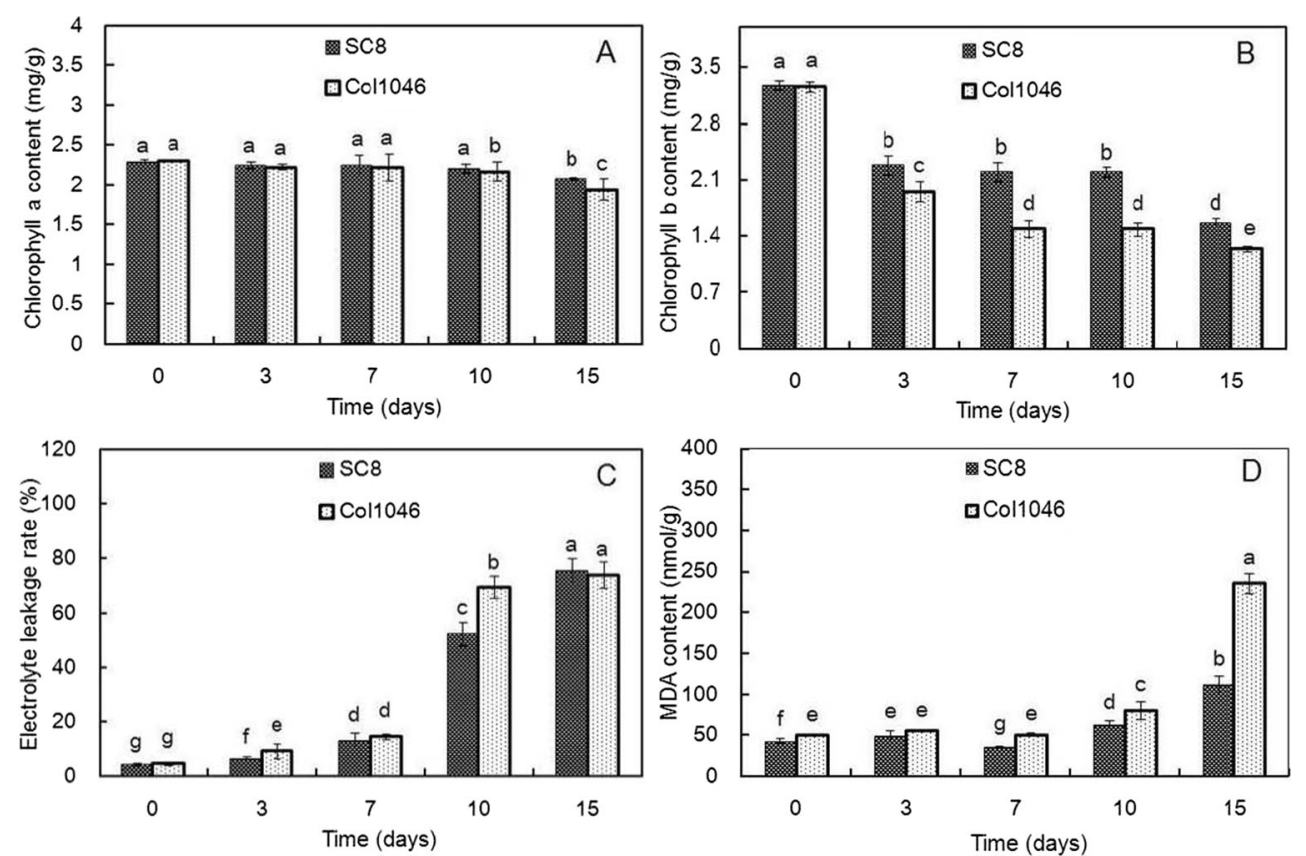

genotypes were gradually increased until reaching the maximum level and then starting to decrease (Fig. 3a, b). The two cassava genotypes had a maximum value of free proline content at 10-day cold stress. SC8 had a maximum value of soluble sugar content at 7-day cold stress; however, Col1046 had a maximum value of soluble sugar content at 10-day cold stress. SOD activities of two genotypes significantly increased under cold stress from 3 to 10 days and then significantly decreased at 15-day cold stress (Fig. 3c). SC8 had the highest SOD activity at 3-day cold stress, but Col1046 had the highest SOD activity at 7-day cold stress (Fig. 3c). Under cold stress, POD activity of two genotypes significantly increased to a maximum level and then started to decrease during 15 days. SC8 had the highest POD activity at 7-day cold stress, but Col1046 had the highest SOD activity at 3-day cold stress (Fig. 3d).

\section{Correlation and Principal Component Analysis of Physiological Parameters}

The correlation analysis of seven physiological and biochemical characteristics (chlorophyll content, EL, MDA content, proline content, soluble sugar content, SOD, and POD) showed that chlorophyll content was
Fig. 3 Content proline and soluble sugar and activities of SOD and POD in cold-stressed cassava apical expanded leaves. Proline contents (a), soluble sugar contents (b), SOD activities (c), and POD activities (d) in SC8 and Col1046 apical leaves exposed to $5{ }^{\circ} \mathrm{C}$ for $0,3,7,10$, and 15 days. The mean values are calculated from three biological replicates; the error bars represent the standard error of the mean
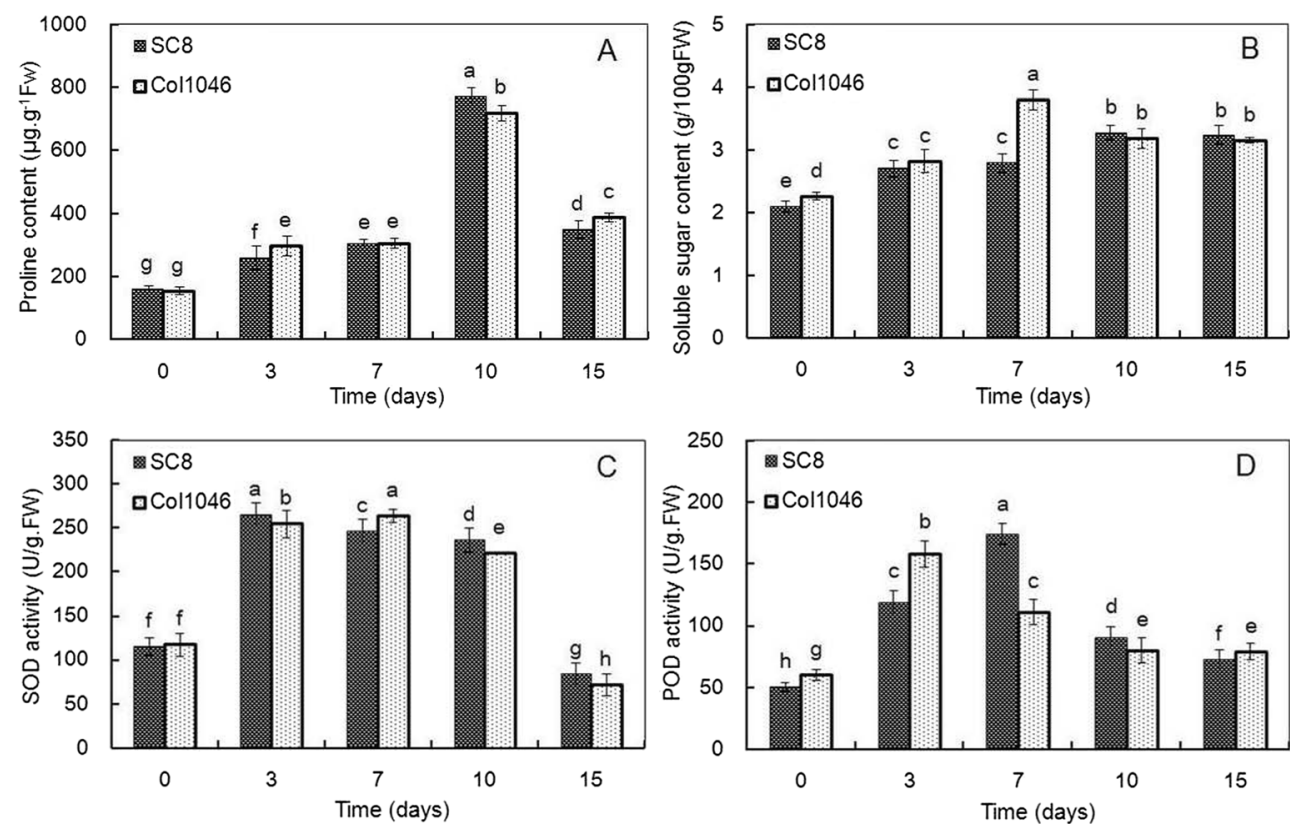
negatively correlated with EL, proline content, MDA content, soluble sugar content, and the activity of SOD and POD and significantly negatively with EL, MDA content, and soluble sugar content; EL was significantly positively related with proline and MDA content; SOD activity and POD activity had a significant positive correlation (Table S1). The principal component (PC) analysis showed that EL, chlorophyll content, and MDA may be the most important physiological and biochemical indexes for determining cassava genotypes with cold-resistant abilities (Table S2).

\section{Protein Profile Responses to Cold Treatment}

Proteins from apical expanded leaves of SC8 and Col1046 were purified from 2D-PAGE gels (Figs. $4 \mathrm{a}, \mathrm{b}$ and $5 \mathrm{a}$ ). In total, $\sim 500$ protein spots were detected by digital image analysis, and at least 300 spots gave reproducible staining patterns for all samples as judged by spot intensity ranking. Using a spot-to-spot comparison and statistical analysis, a total of 45 stained spots (Fig. 4c) in SC8 and 44 stained spots (Fig. 5c) in Col1046 were found to have significant changes $(P<0.05)$ with greater than \pm 2.0 -fold altered intensity in all three

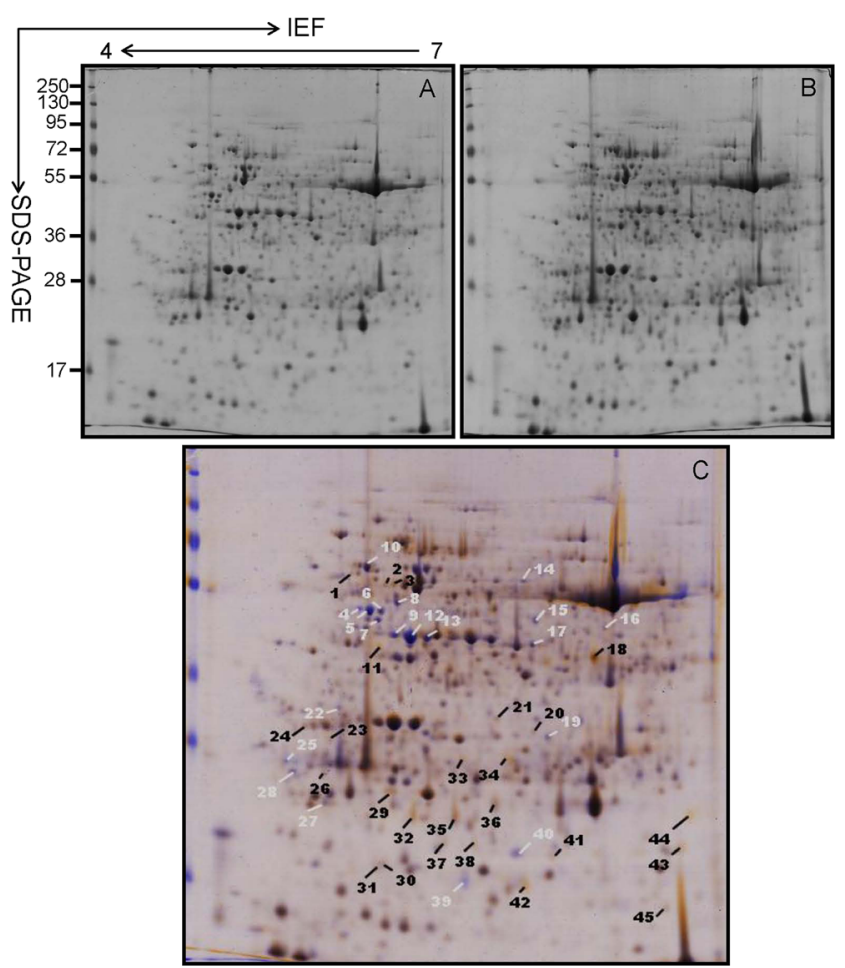

Fig. 4 Coomassie-stained 2-D gel protein profiles of SC8 apical expanded leaves: a $5{ }^{\circ} \mathrm{C}$ for 0 day, b $5{ }^{\circ} \mathrm{C}$ for 10 days, and $\mathbf{c}$ wrapped 2-DE map from $5{ }^{\circ} \mathrm{C}$ for 0 day and $5^{\circ} \mathrm{C}$ for 10 days. The white and black arrows in $\mathbf{c}$ indicate proteins that showed detectable changes $(>2.0$-fold the normalized volume) in abundance compared with those seen in $5^{\circ} \mathrm{C}$ for 0 day; white arrows indicate a down-regulated match, and black arrows indicate an up-regulated match replicate gels. In SC8, the expressions of 20 spots (spots 4 , $5,6,7,8,9,10,12,13,14,15,16,17,19,22,25,27,28,39$, and 40) were down-regulated and the remainders were upregulated (Fig. 4c). The expression of ten spots (spots 3, 11, $18,23,33,36,42,43,56$, and 60) in Col1046 was up-regulated, and the remainders were down-regulated (Fig. 5c).

\section{Functional Grouping of Identified Proteins}

Forty-five spots in SC8 and 44 spots in Col1046 with differential expression were isolated from 2-DE gels and identified with MALDI-TOF-MS/MS, of which 32 and 33 protein spots were identified, respectively. In SC8, 17 identified proteins were up-regulated and 15 were down-regulated response to cold stress. Functions of 32 differentially expressed proteins were annotated via the survey of gene banks (Table 1, Fig. 6a). Ten proteins $(32 \%)$ are associated with photosynthesis metabolism, of which three proteins (spots 20,36, 47) were

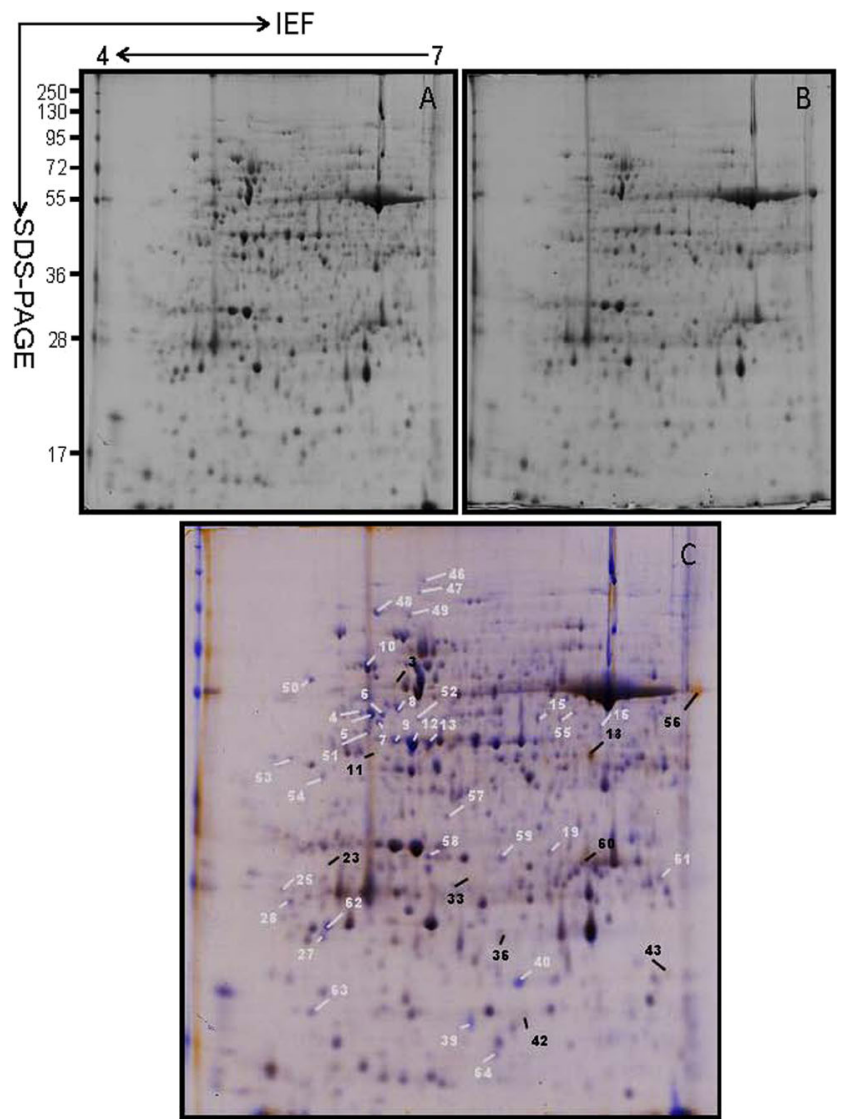

Fig. 5 Coomassie-stained 2-D gel protein profiles of Col1046 apical expanded leaves: a $5{ }^{\circ} \mathrm{C}$ for 0 day, b $5{ }^{\circ} \mathrm{C}$ for 10 days, and $\mathbf{c}$ wrapped 2-DE map from $5{ }^{\circ} \mathrm{C}$ for 0 day and $5{ }^{\circ} \mathrm{C}$ for 10 days. The white and black arrows in $\mathbf{c}$ indicate proteins that showed detectable changes $(>2.0$-fold the normalized volume) in abundance compared with those seen in $5{ }^{\circ} \mathrm{C}$ for 0 day; white arrows indicate a down-regulated match, and black arrows indicate an up-regulated match 
Table 1 Identification of differential expressed proteins in cassava cultivar SC8 tissue culture plantlet apical shoots under low temperature stresses

\begin{tabular}{|c|c|c|c|c|c|}
\hline Spot number ${ }^{\mathrm{a}}$ & Identification & GI no. ${ }^{\mathrm{b}}$ & $\mathrm{pI} / \mathrm{Mw}(\mathrm{kDa})$ & Score $^{\mathrm{c}}$ & Fold changes $^{\mathrm{d}}($ mean $\pm \mathrm{SE})$ \\
\hline \multicolumn{6}{|c|}{ Photosynthesis-related proteins (10) } \\
\hline 4 & Putative Rubisco activase protein-Z. hybrid cultivar & 47176692 & $5.08 / 27.69$ & 71 & $3.03 \pm 0.08(-)$ \\
\hline 5 & Putative Rubisco activase protein-Z. hybrid cultivar & 47176692 & $5.08 / 27.69$ & 90 & $4.41 \pm 0.18(-)$ \\
\hline 6 & Putative Rubisco activase protein-Z. hybrid cultivar & 47176692 & $5.08 / 27.69$ & 86 & $2.64 \pm 0.07(-)$ \\
\hline 7 & Ribulose bisphosphate carboxylase activase- $N$. tabacum & 19988 & $4.83 / 22.98$ & 84 & $3.73 \pm 0.14(-)$ \\
\hline 9 & Putative Rubisco activase protein-Z. hybrid cultivar & 47176692 & $5.08 / 27.69$ & 88 & $2.52 \pm 0.08(-)$ \\
\hline 12 & Ribulose bisphosphate carboxylase activase- $N$. tabacum & 19988 & $4.83 / 22.98$ & 116 & $5.51 \pm 0.24(-)$ \\
\hline 13 & Ribulose bisphosphate carboxylase activase- $N$. tabacum & 19988 & $4.83 / 22.98$ & 98 & $3.17 \pm 0.17(-)$ \\
\hline 20 & $\begin{array}{l}\text { Ribulose bisphosphate carboxylase activase small chain } \\
\text { SU26,chloroplastic }\end{array}$ & 132094 & $8.62 / 19.81$ & 59 & $2.10 \pm 0.07(+)$ \\
\hline 36 & Oxygen-evolving enhancer protein 2,chloroplastic & 131390 & $8.28 / 28.05$ & 47 & $2.28 \pm 0.12(+)$ \\
\hline 41 & $\begin{array}{l}\text { Ribulose } 1,5 \text {-bisphosphate carboxylase small chain } \\
\text { precursor-M. esculenta }\end{array}$ & 6272551 & $8.33 / 20.41$ & 81 & $2.58 \pm 0.12(+)$ \\
\hline \multicolumn{6}{|c|}{ Carbohydrate and energy metabolism-associated proteins (4) } \\
\hline 2 & ATP synthase CF1 beta subunit- $B$. napus & 262400757 & $5.14 / 53.75$ & 92 & $3.50 \pm 0.15(+)$ \\
\hline 3 & ATP synthase subunit beta, chloroplastic & 114557 & $5.15 / 53.47$ & 103 & $2.69 \pm 0.26(+)$ \\
\hline 18 & Phosphoglycerate kinase-A. thaliana & 1022805 & $4.93 / 41.91$ & 111 & $3.92 \pm 0.16(+)$ \\
\hline 21 & Carbohydrate kinase FGGY-K. flavida DSM 17836 & 284028646 & $5.80 / 47.83$ & 75 & $2.07 \pm 0.01(+)$ \\
\hline \multicolumn{6}{|c|}{ Protein biosynthesis (4) } \\
\hline 1 & Integrase catalytic region-Rhizobium sp. PDO1-076 & 375054862 & $9.71 / 59.54$ & 73 & $2.21 \pm 0.05(+)$ \\
\hline 11 & Molybdenum cofactor biosynthesis protein A & 59798352 & $8.38 / 35.62$ & 80 & $\infty(+)$ \\
\hline 28 & Proteasome subunit alpha type- 5 & 12229923 & $4.70 / 25.98$ & 136 & $2.67 \pm 0.10(-)$ \\
\hline 44 & 30S ribosomal protein $\mathrm{S} 3$ & 61215424 & $10.28 / 29.61$ & 71 & $\infty(+)$ \\
\hline \multicolumn{6}{|l|}{ Defense (2) } \\
\hline 19 & $\begin{array}{l}\text { CDSP32 Protein (Chloroplast drought-induced stress } \\
\text { protein of } 32 \mathrm{kDa})-S \text {. tuberosum }\end{array}$ & 2582822 & $8.07 / 33.46$ & 101 & $2.38 \pm 0.13(-)$ \\
\hline 43 & Metacaspase-9-A. thaliana & 75263209 & $5.81 / 35.51$ & 81 & $\infty(+)$ \\
\hline \multicolumn{6}{|c|}{ Detoxifying and antioxidant (3) } \\
\hline 27 & 2-Cys peroxiredoxin-like protein- $H$. orientalis & 47027073 & $4.93 / 21.86$ & 109 & $2.30 \pm 0.11(-)$ \\
\hline 29 & Putative glutathione S-transferase protein-P. tunicata D2 & 88857201 & $5.88 / 24.25$ & 86 & $3.28 \pm 0.23(+)$ \\
\hline 34 & Ascorbate peroxidase APX3-M. esculenta & 62526589 & $5.31 / 27.67$ & 76 & $7.66 \pm 0.52(+)$ \\
\hline \multicolumn{6}{|c|}{ Amino acid metabolism (1) } \\
\hline 39 & $\begin{array}{l}\text { 5-Methyltetrahydropteroyltriglutamate/homocysteine } \\
\text { S-methyltransferase-Metallosphaera sedula DSM } 5348\end{array}$ & 146304995 & $9.54 / 36.30$ & 88 & $23.6 \pm 1.23(-)$ \\
\hline \multicolumn{6}{|l|}{ Chaperones (1) } \\
\hline 10 & Rubisco subunit binding-protein alpha subunit- $R$. communis & 255587664 & $5.25 / 53.20$ & 177 & $2.13 \pm 0.06(-)$ \\
\hline \multicolumn{6}{|c|}{ DNA binding proteins (1) } \\
\hline 40 & DNA-binding protein-Z. mays & 397396 & $5.87 / 18.29$ & 59 & $3.60 \pm 0.31(-)$ \\
\hline \multicolumn{6}{|c|}{ Protein metabolism (1) } \\
\hline 26 & $\begin{array}{l}\text { ATP-dependent Clp protease proteolytic subunit- } A \text {. } \\
\text { thaliana }\end{array}$ & 21593305 & $5.37 / 31.51$ & 58 & $2.17 \pm 0.04(+)$ \\
\hline \multicolumn{6}{|c|}{ Signal transduction mechanisms $(1)$} \\
\hline 23 & 14-3-3-like protein & 12229593 & $4.79 / 29.25$ & 84 & $\infty(+)$ \\
\hline \multicolumn{6}{|l|}{ Structure (1) } \\
\hline 42 & Similar to actin-binding protein- $A$. thaliana & 3047107 & $5.12 / 15.70$ & 44 & $\infty(+)$ \\
\hline \multicolumn{6}{|c|}{ Function unknown proteins (3) } \\
\hline 17 & Hypothetical protein-P. anserina $S$ mat & 171680357 & $9.61 / 31.52$ & 85 & $2.09 \pm 0.02(-)$ \\
\hline 22 & Hypothetical protein- $V$. vinifera & 147800453 & $5.43 / 49.83$ & 68 & $2.58 \pm 0.13(-)$ \\
\hline 31 & Hypothetical protein-E. siliculosus & 298710091 & $6.15 / 18.19$ & 97 & $2.06 \pm 0.02(+)$ \\
\hline \multicolumn{2}{|c|}{ The total protein number } & 32 & & & \\
\hline
\end{tabular}

After gel analysis and manual editing with Delta2D software, the spots showing altered expression ( $>2.0$-fold the normalized volume) were counted. Each value represents the mean \pm SE of triplicates. Protein spots whose abundance increased $(+)$ or decreased $(-)$ after polyploidy are shown

${ }^{\mathrm{a}}$ The numbering corresponds to the 2-DE gel in Fig. $4 \mathrm{c}$

${ }^{\mathrm{b}}$ GI number

${ }^{\mathrm{c}}$ Probability-based molecular weight search (MOWSE) scores

${ }^{\mathrm{d}}$ Expression change level after cold stress

down-regulated. Four up-regulated proteins $(13 \%)$ were associated with carbohydrate and energy metabolism, and four proteins $(13 \%)$ were involved in protein biosynthesis including one protein (spot 28), which was 
Fig. 6 Functional categories of differential proteins. a Functional categories of differential proteins in SC8 apical expanded leaves exposed to $5{ }^{\circ} \mathrm{C}$ for 10 days compared with $5{ }^{\circ} \mathrm{C}$ for 0 day. $\mathbf{b}$ Functional categories of differential proteins in Col1046 apical expanded leaves exposed to $5^{\circ} \mathrm{C}$ for 10 days compared with $5{ }^{\circ} \mathrm{C}$ for 0 day. Functional categorization was performed according to MIPS database (http://mips.gsf.de)
A

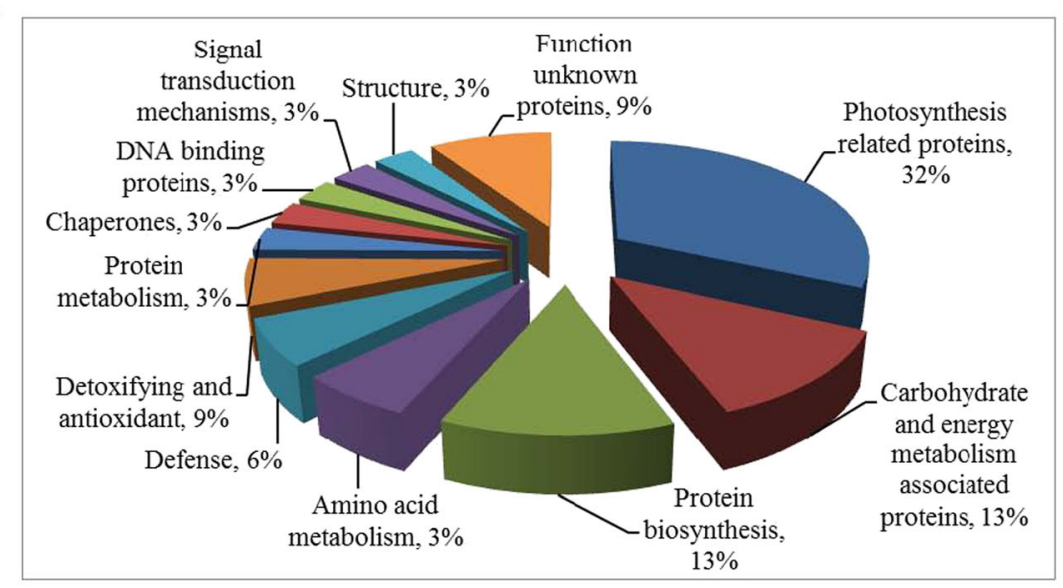

B

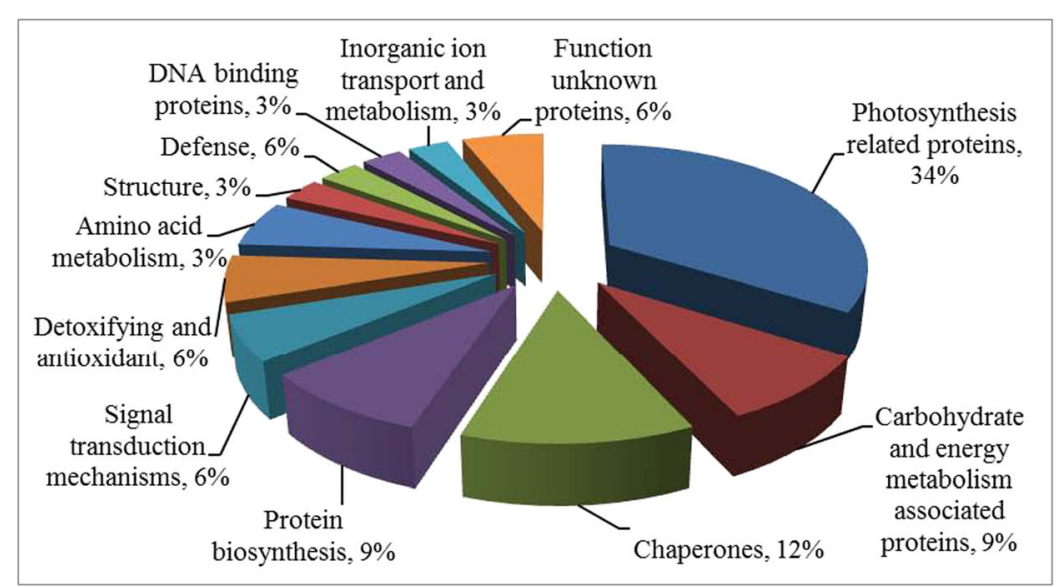

down-regulated. Two proteins $(6 \%)$ in defense system and spot 19 were down-regulated, three proteins (9\%) in detoxifying and antioxidant and spot 27 was downregulated, one down-regulated protein (3\%) in amino acid metabolism, one up-regulated protein (3\%) with signal transduction, one up-regulated protein (3\%) with structure, one up-regulated protein (3\%) with protein metabolism, one down-regulated protein (3\%) with chaperones, and one down-regulated protein (3\%) with DNA binding. Other three were function-unknown proteins, including two down-regulated proteins.

In Col1046, nine identified proteins were up-regulated and 24 were down-regulated response to cold stress. Functions of 33 differentially expressed proteins were annotated via the survey of gene banks (Table 2, Fig. 6b). Eleven proteins (34\%) are associated with photosynthesis metabolism, of which two proteins (spots 36, 60) were up-regulated. Four down-regulated proteins $(12 \%)$ were chaperones, three proteins $(9 \%)$ were associated with carbohydrate and energy metabolism including one down-regulated protein (spot 52), and three proteins ( $9 \%$ ) were involved in protein biosynthesis including one protein (spot 11), which was up-regulated. Two proteins $(6 \%)$ were involved in defense system, two down- regulated proteins $(6 \%)$ in detoxifying and antioxidant, and one down-regulated protein $(3 \%)$ in amino acid metabolism. Two up-regulated proteins $(6 \%)$ were associated with signal transduction, one up-regulated protein (3\%) with structure, one down-regulated protein (3\%) with inorganic ion transport and metabolism, and one down-regulated protein (3\%) with DNA binding. Other two down-regulated spots were functionunknown proteins.

As shown in Fig. 7a, 25 differential spots showed the same changes in SC8 and Col1046, of which 20 protein spots were identified and functions were annotated (Fig. 7b). Eight proteins $(40 \%)$ are associated with photosynthesis metabolism, of which spot 36 was up-regulated. Two up-regulated proteins (10\%) were associated with carbohydrate and energy metabolism, and two proteins (10\%) were involved in protein biosynthesis including one protein (spot 11), which was up-regulated. Spot 39 (5\%) in amino acid metabolism was downregulated. One down-regulated protein $(5 \%)$ was chaperone, and two proteins $(10 \%)$ were in defense system, one downregulated protein $(5 \%)$ in detoxifying and antioxidant, and one down-regulated protein $(5 \%)$ with DNA binding. One up-regulated protein $(5 \%)$ was with signal transduction and one up-regulated protein $(5 \%)$ with structure. 
Table 2 Identification of differential expressed proteins in cassava cultivar Col1046 tissue culture plantlet apical shoots under low temperature stresses

\begin{tabular}{|c|c|c|c|c|c|}
\hline Spot number ${ }^{\mathrm{a}}$ & Identification & GI no. ${ }^{b}$ & $\mathrm{pI} / \mathrm{Mw}(\mathrm{kDa})$ & Score $^{\mathrm{c}}$ & Fold changes $^{\mathrm{d}}($ mean $\pm \mathrm{SE})$ \\
\hline \multicolumn{6}{|c|}{ Photosynthesis-related proteins (11) } \\
\hline 4 & Putative Rubisco activase protein-Z. hybrid cultivar & 47176692 & $5.08 / 27.69$ & 71 & $4.67 \pm 0.34(-)$ \\
\hline 5 & Putative Rubisco activase protein-Z. hybrid cultivar & 47176692 & $5.08 / 27.69$ & 90 & $2.43 \pm 0.23(-)$ \\
\hline 6 & Putative Rubisco activase protein-Z. hybrid cultivar & 47176692 & $5.08 / 27.69$ & 86 & $2.49 \pm 0.12(-)$ \\
\hline 7 & Ribulose bisphosphate carboxylase activase- $N$. tabacum & 19988 & $4.83 / 22.98$ & 84 & $3.76 \pm 0.36(-)$ \\
\hline 9 & Putative Rubisco activase protein-Z. hybrid cultivar & 47176692 & $5.08 / 27.69$ & 88 & $2.13 \pm 0.12(-)$ \\
\hline 12 & Ribulose bisphosphate carboxylase activase-N. tabacum & 19988 & $4.83 / 22.98$ & 116 & $2.83 \pm 0.43(-)$ \\
\hline 13 & Ribulose bisphosphate carboxylase activase-N. tabacum & 19988 & $4.83 / 22.98$ & 98 & $2.93 \pm 0.35(-)$ \\
\hline 36 & Oxygen-evolving enhancer protein 2 , chloroplastic & 131390 & $8.28 / 28.05$ & 47 & $2.12 \pm 0.1(+)$ \\
\hline 51 & Ribulose bisphosphate carboxylase activase- $N$. tabacum & 19988 & $4.83 / 22.98$ & 78 & $2.06 \pm 0.02(-)$ \\
\hline 60 & Carbonic anhydrase, chloroplastic & 115472 & $6.61 / 34.57$ & 131 & $2.31 \pm 0.21(+)$ \\
\hline 61 & Carbonic anhydrase, chloroplastic & 115472 & $6.61 / 34.57$ & 105 & $3.61 \pm 0.25(-)$ \\
\hline \multicolumn{6}{|c|}{ Carbohydrate and energy metabolism-associated proteins (3) } \\
\hline 3 & ATP synthase subunit beta, chloroplastic & 114557 & $5.15 / 53.47$ & 103 & $\infty(+)$ \\
\hline 18 & Phosphoglycerate kinase-A. thaliana & 1022805 & $4.93 / 41.91$ & 111 & $7.22 \pm 0.63(+)$ \\
\hline 52 & Succinate dehydrogenase- $R$. communis & 255579273 & $6.18 / 68.51$ & 117 & $3.24 \pm 0.28(-)$ \\
\hline \multicolumn{6}{|c|}{ Protein biosynthesis (3) } \\
\hline 11 & Molybdenum cofactor biosynthesis protein A & 59798352 & $8.38 / 35.62$ & 80 & $\infty(+)$ \\
\hline 28 & Proteasome subunit alpha type- 5 & 122299231 & $4.70 / 25.98$ & 136 & $2.07 \pm 0.06(-)$ \\
\hline 58 & Uncharacterized HTH-type transcriptional regulator & 1176726 & $8.72 / 21.35$ & 70 & $2.59 \pm 0.03(-)$ \\
\hline \multicolumn{6}{|c|}{ 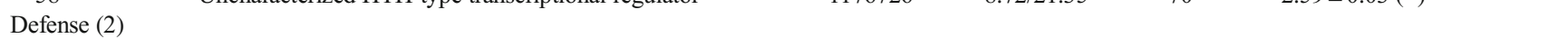 } \\
\hline 19 & $\begin{array}{l}\text { Chloroplast drought-induced stress protein of } 32 \mathrm{kDa} \\
\text { (CDSP32 protein)-S. tuberosum }\end{array}$ & 2582822 & $8.07 / 33.46$ & 101 & $2.65 \pm 0.34(-)$ \\
\hline 43 & Metacaspase-9-A. thaliana & 75263209 & $5.81 / 35.51$ & 81 & $5.45 \pm 0.47(+)$ \\
\hline \multicolumn{6}{|c|}{ Detoxifying and antioxidant (2) } \\
\hline 27 & 2-Cys peroxiredoxin-like protein- $H$. orientalis & 47027073 & $4.93 / 21.86$ & 109 & $2.23 \pm 0.21(-)$ \\
\hline 62 & Peroxiredoxin- $P$. vulgaris & 11558242 & $5.18 / 28.62$ & 123 & $2.01 \pm 0.05(-)$ \\
\hline \multicolumn{6}{|c|}{ Amino acid metabolism (1) } \\
\hline 39 & $\begin{array}{l}\text { 5-Methyltetrahydropteroyltriglutamate/homocysteine } \\
\text { S-methyltransferase-Metallosphaera sedula DSM } 5348\end{array}$ & 146304995 & $9.54 / 36.30$ & 88 & $25.74 \pm 2.36(-)$ \\
\hline \multicolumn{6}{|l|}{ Chaperones (4) } \\
\hline 10 & Rubisco subunit binding-protein alpha subunit-R. communis & 255587664 & $5.25 / 53.20$ & 177 & $2.00 \pm 0.02(-)$ \\
\hline 57 & Shoot1 protein-G. $\max$ & 13650078 & $5.26 / 40.24$ & 91 & $2.07 \pm 0.04(-)$ \\
\hline 59 & Binding/catalytic/coenzyme binding- $A$. thaliana & 18404496 & $8.37 / 34.88$ & 263 & $2.19 \pm 0.09(-)$ \\
\hline 64 & HSP19 class II-Citrus $\times$ paradisi & 30575570 & $8.01 / 11.14$ & 67 & $2.05 \pm 0.06(-)$ \\
\hline \multicolumn{6}{|c|}{ DNA binding proteins $(1)$} \\
\hline 40 & DNA-binding protein-Z. mays & 397396 & $5.87 / 18.29$ & 59 & $6.49 \pm 0.56(-)$ \\
\hline \multicolumn{6}{|c|}{ Signal transduction mechanisms (2) } \\
\hline 23 & 14-3-3-like protein & 12229593 & $4.79 / 29.25$ & 84 & $34.11 \pm 2.56(+)$ \\
\hline 56 & Adenylate cyclase-like protein-Thermus thermophilus HB8 & 55981228 & $9.76 / 95.97$ & 91 & $18.92 \pm 1.54(+)$ \\
\hline \multicolumn{6}{|l|}{ Structure (1) } \\
\hline 42 & Similar to actin-binding protein-A. thaliana & 3047107 & $5.12 / 15.70$ & 44 & $3.72 \pm 0.56(+)$ \\
\hline \multicolumn{6}{|c|}{ Inorganic ion transport and metabolism (1) } \\
\hline 50 & Calreticulin-A. thaliana & 1009712 & $4.37 / 46.58$ & 228 & $2.09 \pm 0.02(-)$ \\
\hline \multicolumn{6}{|c|}{ Function unknown proteins (2) } \\
\hline 48 & Hypothetical protein-S. moellendorffii & 302784390 & $8.40 / 91.35$ & 76 & $2.90 \pm 0.07(-)$ \\
\hline 63 & Unknown protein- $A$. thaliana & 4567284 & $9.30 / 25.55$ & 88 & $2.03 \pm 0.03(-)$ \\
\hline \multicolumn{2}{|c|}{ The total protein number } & 33 & & & \\
\hline
\end{tabular}

After gel analysis and manual editing with Delta2D software, the spots showing altered expression $(>2.0$-fold the normalized volume $)$ were counted. Each value represents the mean \pm SE of triplicates. Protein spots whose abundance increased $(+)$ or decreased $(-)$ after polyploidy are shown

${ }^{\mathrm{a}}$ The numbering corresponds to the 2-DE gel in Fig. $5 \mathrm{c}$

${ }^{\mathrm{b}} \mathrm{GI}$ number

${ }^{\mathrm{c}}$ Probability-based molecular weight search (MOWSE) scores

${ }^{\mathrm{d}}$ Expression change level after cold stress

To ensure reliability of differential proteins observed on 2DE gels, the protein expressions of Rubisco and peroxiredoxin in apical expanded leaves of cassava SC8 and Col1046 exposed to cold stress for 10 days were detected by
Western blot to validate the proteomic analysis (Fig. 8). The results showed that the expression levels of Rubisco and peroxiredoxin in SC8 and Col1046 were similar with those seen on 2-DE images (Figs. 4 and 5). 
Fig. 7 Functional categories of the common differential proteins identified in both SC8 and Col1046 apical expanded leaves exposed to $5^{\circ} \mathrm{C}$ for 10 days compared with $5{ }^{\circ} \mathrm{C}$ for 0 day. a Number of spots altered in expression of SC8 and Col1046. b Functional categories of 20 common differential proteins in SC8 and Col1046
A

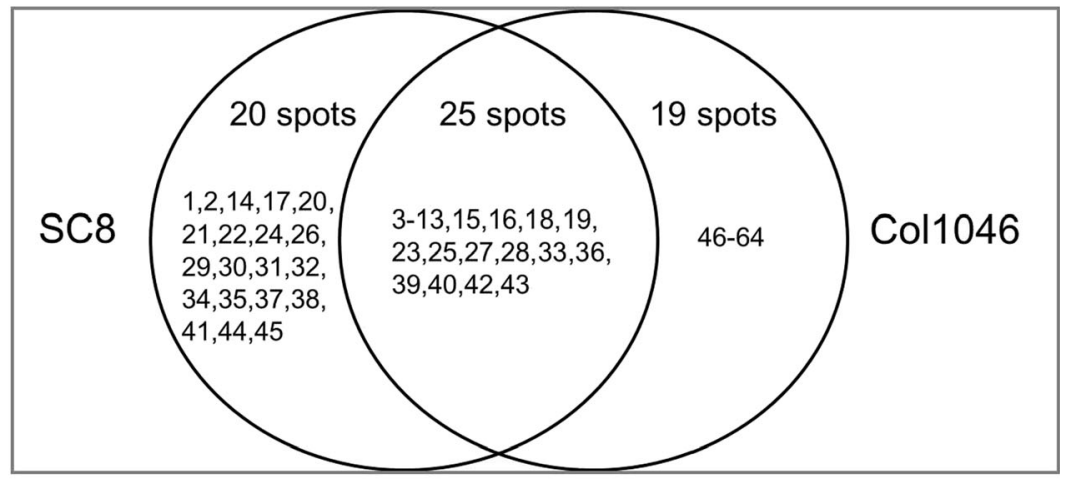

B

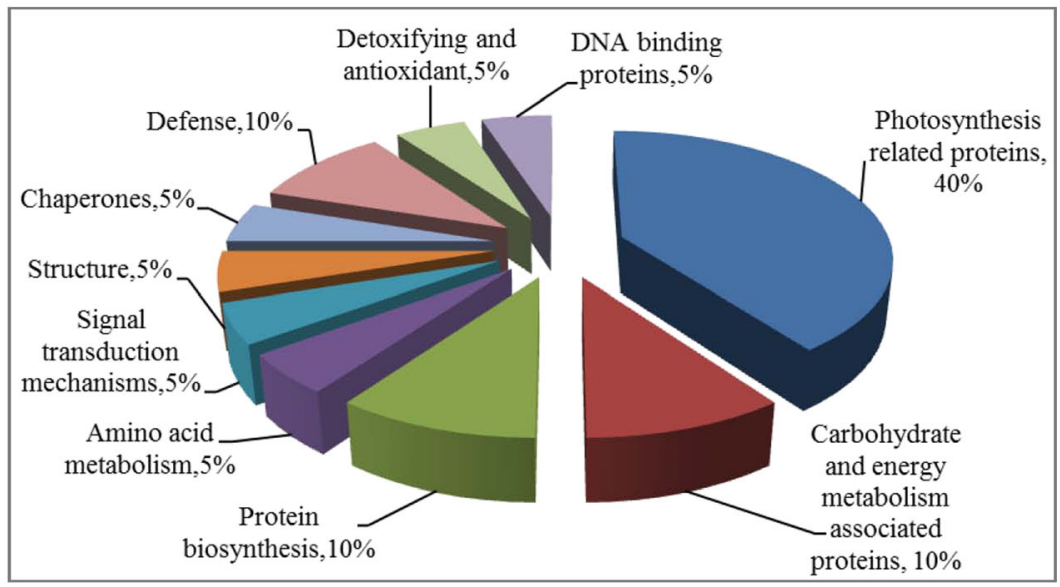

\section{Photosynthetic Activities in Low-Temperature-Treated Cassava}

In order to understand the effects of cold stress on the photosynthetic activities of cassava in vitro plants, the photosynthesis parameters $\mathrm{Fv} / \mathrm{Fm}, \Phi \mathrm{PSII}, \mathrm{NPQ} / 4$, and $\mathrm{qN}$ of the 10-day cold stress leaves of SC8 and Col1046 were determined using Imaging-PAM. Figure 9 and Table 3 show that the Fv/Fm and $\Phi$ PSII of both genotypes were sensitive to low temperature and decreased significantly; however, NPQ/4 and $\mathrm{qN}$ were increased significantly. These data imply down-regulated proteins associated with photosynthesis may result in decrease of photosynthetic activities under cold stress.
Fig. 8 Western blotting of Rubisco and peroxiredoxin. The expressions of Rubisco (a) and peroxiredoxin (b) in apical expanded leaves of SC8and Col1046 were detected by Western blotting using antiRubisco polyclonal antibody (AS07218) and antiperoxiredoxin antibody (AS05093) from Agrisera, respectively. $M r$, protein marker; lines $a$ and $b$, the expression of Rubisco and peroxiredoxin of SC 8 in $5{ }^{\circ} \mathrm{C}$ for 0 and 10 days, respectively; lines $c$ and $d$, the expression of Rubisco and peroxiredoxin of Co11046 in $5^{\circ} \mathrm{C}$ for 0 and 10 days, respectively
A

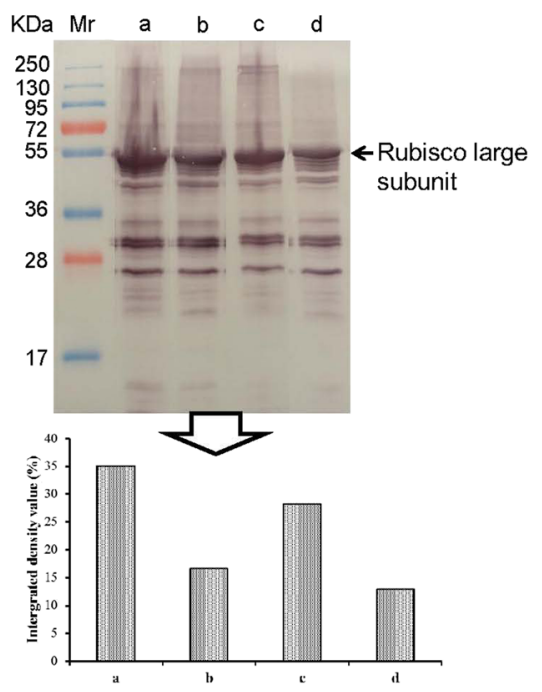

B

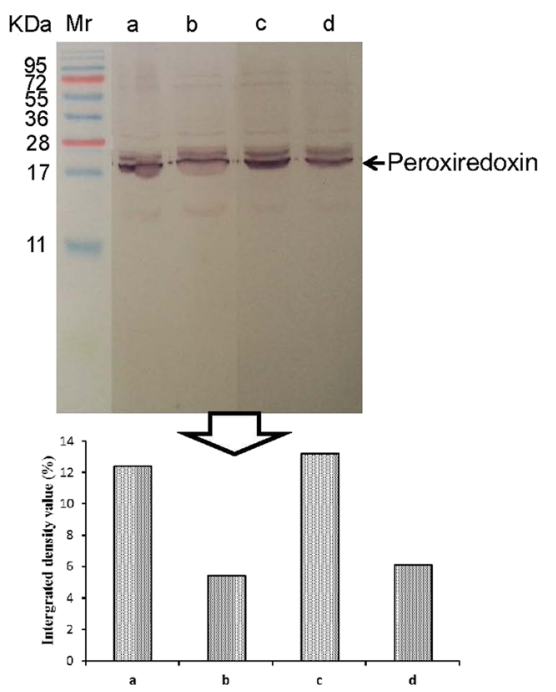


Fig. 9 Imaging pulse amplitude modulation of SC8 and Col1046 collected from apical expanded leaves exposed to $5{ }^{\circ} \mathrm{C}$ for 0 and 10 days. Parameters were Fv/Fm (maximal photosystem II (PSII) quantum yield), ФPSII (effective PSII quantum yield), and NPQ/4 (non photochemical quenching). The color gradient provided a scale from 0 to $100 \%$ for assessing the magnitude of the parameters

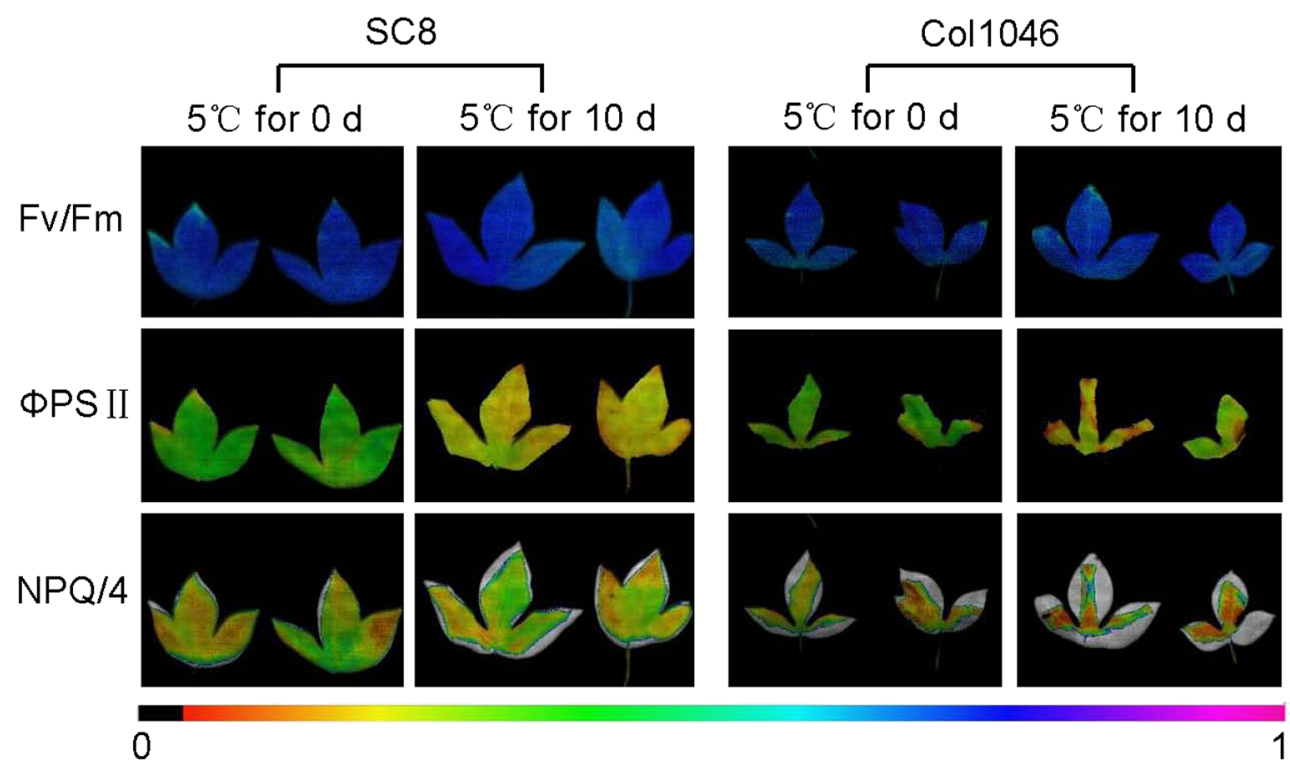

Protein Interaction Networks

All differential proteins identified were used to generate a wider protein interaction map by employing a Pathway Studio software program (Fig. 10). The relationships of binding, regulation, and chemical reaction were established for 11 differential proteins, responding to plant photosynthesis, yield, stresses, and cold. CDSP32 is localized in the chloroplast. There are direct interactions between 11 proteins, including ATP synthase subunit beta, Rubisco activase (RCA), Rubisco, phosphoglycerate kinase, APX, CDSP32, peroxiredoxin, chaperone, heat shock protein, glutathione transferase, and 143-3, whereas RCA can establish relations with other proteins through regulating the processes of photosynthesis and plant yield. The differential proteins including RCA and Rubisco activase, involved with photosynthetic biosynthesis, and CDSP32 and peroxiredoxin, related with stress, were decreased in both cassava genotypes under cold stress.

\section{Discussions}

Cold stress adversely affects plant growth and development. Most temperate plants acquire cold tolerance by a process called cold acclimation (Chinnusamy et al. 2007). Low temperature has been regarded as a major stress for crops, and its negative effects have been studied extensively (Lyons 1973; Wettstein et al. 1995; Li et al. 2012). Proteomics was not only applied to describe the whole proteomes for the cell, tissue, organelle, and the total plants, but also used as a powerful tool for detecting the changes of the global proteins affected by the exposure to cold or other extreme environmental factors. Cassava proteomes could be identified using SDS-PAGE and 2-DE in combination with mass spectrometry and iTRAQ-based analysis, which have contributed to understanding the mechanism of storage root formation and the pathways associated with post-harvest physiological deterioration (Owiti et al. 2011; Batista de Souza et al. 2015). Comparative proteomic approaches were also applied to monitor differentially expressed leaf proteins during root transition
Table 3 Photosynthetic parameters collected from cassava apical shoots of SC8, Col1046, and treatments

\begin{tabular}{|c|c|c|c|c|}
\hline Treatment & $\begin{array}{l}\mathrm{Fv} / \mathrm{Fm} \\
(\mathrm{mean} \pm \mathrm{SE})\end{array}$ & $\begin{array}{l}\text { ФPSII } \\
(\text { mean } \pm \text { SE })\end{array}$ & $\begin{array}{l}\mathrm{NPQ} / 4 \\
(\mathrm{mean} \pm \mathrm{SE})\end{array}$ & $\begin{array}{l}\mathrm{qN} \\
(\text { mean } \pm \mathrm{SE})\end{array}$ \\
\hline $\mathrm{SC} 8$ at $5{ }^{\circ} \mathrm{C}$ for 0 day & $0.725 \pm 0.006 \mathrm{~A}$ & $0.371 \pm 0.016 \mathrm{~A}$ & $0.167 \pm 0.023 \mathrm{~B}$ & $\begin{array}{l}0.537 \pm 0.012 \\
\text { B }\end{array}$ \\
\hline $\mathrm{SC} 8$ at $5{ }^{\circ} \mathrm{C}$ for 10 days & $0.684 \pm 0.008 \mathrm{~B}$ & $0.198 \pm 0.011 \mathrm{~B}$ & $0.278 \pm 0.015 \mathrm{~A}$ & $\begin{array}{l}0.675 \pm 0.008 \\
\mathrm{~A}\end{array}$ \\
\hline Col1046 at $5{ }^{\circ} \mathrm{C}$ for 0 day & $0.718 \pm 0.012 \mathrm{~A}$ & $0.353 \pm 0.010 \mathrm{~A}$ & $0.267 \pm 0.015 \mathrm{~B}$ & $\begin{array}{l}0.646 \pm 0.043 \\
\text { B }\end{array}$ \\
\hline $\begin{array}{l}\text { Col1046 at } 5{ }^{\circ} \mathrm{C} \text { for } \\
10 \text { days }\end{array}$ & $0.675 \pm 0.007 \mathrm{~B}$ & $0.227 \pm 0.009 \mathrm{~B}$ & $0.422 \pm 0.013 \mathrm{~A}$ & $\begin{array}{l}0.782 \pm 0.013 \\
\mathrm{~A}\end{array}$ \\
\hline
\end{tabular}

Values were means \pm SE. Different capital letters in the same column indicated statistically significant differences according to Duncan test $(P<0.01)$ 


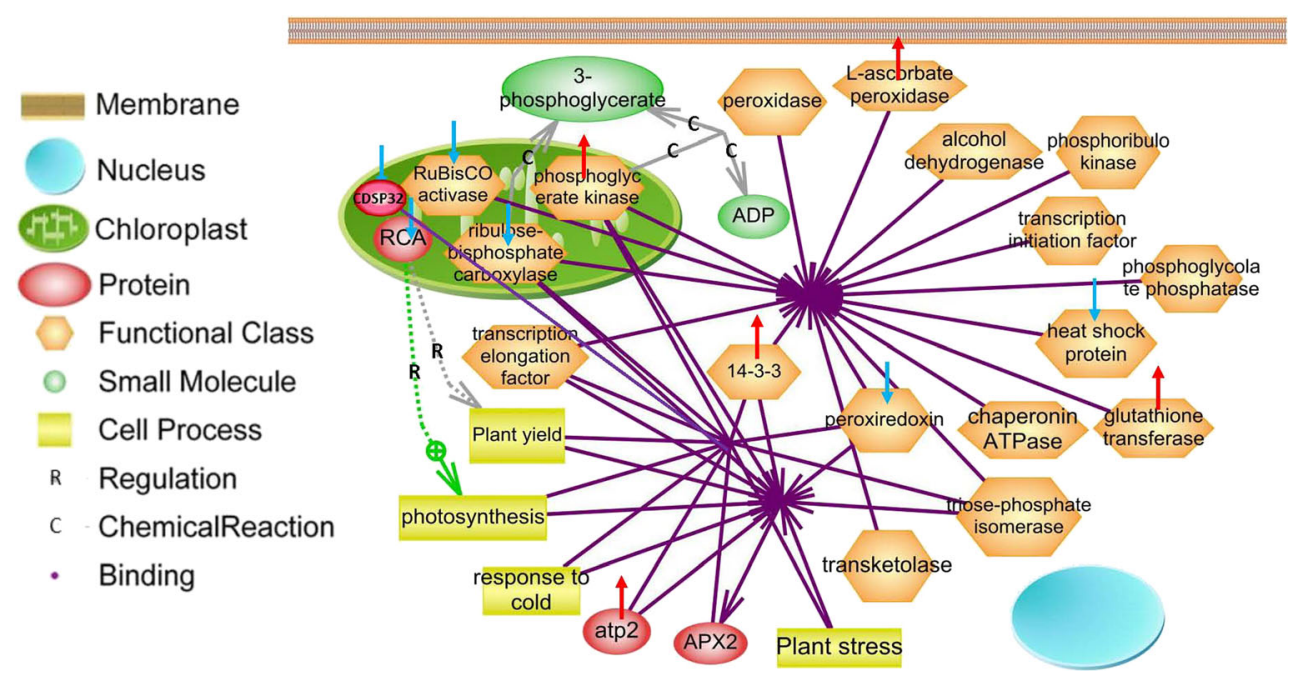

Fig. 10 Biological networks generated for combination of 11 differential proteins. Differential proteins including ATP synthase subunit beta, RCA, Rubisco, phosphoglycerate kinase, APX, CDSP32, peroxiredoxin, chaperone, heat shock protein, glutathione transferase, and 14-3-3 were used to generate a protein-protein interaction network through Pathway
Studio analysis. Regulation is marked as an arrow with $R$, chemical reaction as an arrow with $C$, and binding as an arrow without any marks. Blue arrows indicate down-regulated expression, and read indicates up-regulated expression (Color figure online)

(Wang et al. 2009). Another protein that dramatically increased in abundance during cold stress is 14-3-3 protein (spot 23). In plants, 14-3-3 proteins are reported to play a significant role in regulating primary metabolism, signal transduction, and subcellular and defense reactions (Ferl 2004; Roberts 2003). They were also identified as drought-responsive proteins (Zhao et al. 2015). Through binding kinases and phosphatases and then regulating their activities, 14-3-3 proteins can be used as integral components of signal transduction pathways (Aitken 1995; Camoni et al. 1998; Sehnke et al. 2002). In the present study, the changes of material and energy metabolism may result from the signal transduction irritated by cold stress. As shown in Tables 1 and 2 and Figs. 4 and 5, 67 and $58 \%$ changed proteins in SC8 and Col1046, respectively, were involved in material and energy metabolism (photosynthesis, carbohydrate and energy metabolism, protein biosynthesis, and amino acid metabolism). This suggests that altered metabolism seems to play an appreciable role in the cold response of cassava. Specifically, photosynthesis appears to be inhibited, as evidenced by the expressed decrease in photosynthetic apparatus proteins, such as seven down-regulated spots and three downregulated spots in SC8 and nine down-regulated spots and two up-regulated spots in Co11046, inferring that the photosynthetic levels of both cassava plants were decreased. These data were confirmed by the analysis of SC 8 and Co11046 chlorophyll a and chlorophyll $b$ contents (Fig. 2a, b). These altered proteins might protect cassava leaves from photo-inhibition, which is typically aggravated when abiotic stresses are accompanied by light stress (Moon et al. 1995). In the present study, the expressions of Rubisco activase small chain SU26 (spot 20) and oxygenevolving enhancer protein (spot 36) were increased. This result was similar as that shown under high salinity (Wang et al. 2008). The role of increased Rubisco levels in abiotic stress requires 
further clarification. In contrast to the apparent decrease in the expression of photosynthesis-related proteins, the activities of carbohydrate and energy metabolism-associated proteins were enhanced during the cold stress, including ATP synthase (spots 2 and 3), phosphoglycerate kinase (spot 18), and carbohydrate kinase FGGY (spot 21). All these proteins are enzymes of either the glycolysis or the TCA cycle pathways, which might ensure the energy flow as well as reductants to help cassava in resisting cold stress. The activities of protein biosynthesis-related proteins (three up-regulated spots, 1, 11, and 44; one down-regulated spot, 28 ) in SC8 genotype were increased under cold stress, suggesting a heightened production regarding protein synthesis. However, the activities of 5-methyltetrahydropteroyltriglutamate/homocysteine S-methyltransferase (spot 39) in both genotypes associated with amino acid metabolism were decreased under cold stress; its contribution to cassava cold resistance is still elusive.

Along with the above-mentioned components of signal transduction (spot 23), cold stress also up-regulated several proteins typically associated with defense, detoxifying, and antioxidant (spots 29, 34, and 43) (Wang et al. 2009). However, the heat shock proteins (HSPs) are an important class of defense proteins, which is a large and diverse group of molecular chaperones (Chen et al. 2009). Small HSPs were also supposed to act in association with other HSP like HSP70; they are particularly involved in stabilizing protein conformation by preventing the aggregation of denatured or incompletely folded proteins and by promoting the re-naturation of aggregated proteins (Boston et al. 1996). Stabilizing and refolding proteins with HSPs were reported as a major mechanism of cold resistance in plants (Thomashow 1998). HSP19 (spot 64), identified in Col1046, was previously described as developmental and stress response in tomato fruit (Neta-Sharir et al. 2005); CDSP32 (spot 19), a thioredoxin induced by extremely environmental stresses, is also a defense protein (Rey et al. 2005). Metacaspase (spot 43) was an up-regulated defense-related protein in the present study. It induced programmed cell death in plants and was arginine/ lysine specific (Vercammen et al. 2004; Bozhkov et al. 2005).

Plants exposed to cold temperatures would generate reactive oxygen species (ROS). The previous studies reported that detoxifying-and-antioxidant-associated proteins, such as SOD and APX, were up-regulated to eliminate excess ROS under extremely environmental stresses (Sairam et al. 2005; Cavalcanti et al. 2007; Chen and Heuer 2013). SOD converts superoxide to the less toxic hydrogen peroxide $\left(\mathrm{H}_{2} \mathrm{O}_{2}\right)$ molecule, and its function as an antioxidant has been reported in response to various abiotic stresses (Torabi et al. 2009; Parker et al. 2006; Gazanchian et al. 2007). The detoxification of $\mathrm{H}_{2} \mathrm{O}_{2}$ may be accomplished with antioxidant enzymes such as APX (spot 34) and 2-cys peroxiredoxin (spot 27), a member of a ubiquitous group of peroxidases that reduce $\mathrm{H}_{2} \mathrm{O}_{2}$ and alkyl hydroperoxide (Dietz et al. 2002). 2-Cys peroxiredoxin was down-regulated in SC8 and Col1046 under cold stress in the present study, suggesting that 2-cys peroxiredoxin-dependent water-water cycle would be an important alternative to detoxify $\mathrm{H}_{2} \mathrm{O}_{2}$ under oxidative stress (Hajheidari et al. 2005; Ali and Komatsu 2006; Hajheidari et al. 2007). Glutathione S-transferase (GST) (spot 29) was only upregulated in SC8. It limits oxidative damage by removing ROS (Edwards et al. 2000). This may partly explain the reason that cassava SC8 has more cold-tolerant ability than Col1046, confirmed by the data analysis of EL and MDA content shown in Fig. 2c, d. Overall, the predominant changes in the expressions of global proteins related to oxidative stress defense underscore the importance of managing ROS and oxidative damage during cold acclimation and the protection of plant cells (Wang et al. 2009).

\section{Conclusions}

In the present study, the dynamic expression changes of physiology and proteome in cassava genotypes SC8 and Col1046 have shown that cold-induced response would be an integrative process controlled by the complex biological networks involved in 64 differential proteins classified into 11 functions. Cassava cells might sense cold stress through low-temperature-induced responses in the plasma membrane and then transduce the cold stress signaling to plant defense system by 14-3-3 proteinmediated pathway. The whole defense system involved in the proteins associated with photosynthesis, carbohydrate and energy metabolism, defense, detoxifying and antioxidant, and signal transduction might elucidate the molecular mechanisms related to low temperature stress, reflecting that the trend is consistent with the physiological responses. These data should provide a useful clue to develop a complete understanding of how the plant cell responds and survives in the face of low temperatures.

Acknowledgments This work was supported by the National Scientific and Technological Programs in Rural Fields (2012AA101204-2), the Initial Fund of High-level Creative Talents in Hainan Province, the National Science and Technology Infrastructure Program (2015BAD15B01), the CATAS Science and Technology Research Project (1630032015005), and the Earmarked Fund for Modern Agro-industry Technology Research System (nycytx-17). We thank Wenli Zhu and Ruili Xu (TCGRI, CATAS) for providing the cassava cultivars SC8 and Col1046 introduced from CIAT from Cassava Germplasm Collection Pool, TCGRI, CATAS.

Authors' Contributions Songbi Chen made the major contributions to this study in the conception, design, drafting manuscript, final revision, and part of protein identification. Feifei An contributed to part of design, 2-D gel profiles, protein identification, and drafting part of manuscript. Genghu Li worked at cassava plantlets grown from tissue cultures, protein extraction, and part of protein data analysis. Qing X Li and Luiz JCB Carvalho contributed to the protein identification. Wenjun Ou worked at physiological and biochemical characteristics, and Kaimian Li participated to part of design and protein data analysis and critical revision of manuscript. All authors read and approved the final manuscript.

\section{Compliance with Ethical Standards}

Conflict of Interest The authors declare that they have no competing interests. 
Open Access This article is distributed under the terms of the Creative Commons Attribution 4.0 International License (http:// creativecommons.org/licenses/by/4.0/), which permits unrestricted use, distribution, and reproduction in any medium, provided you give appropriate credit to the original author(s) and the source, provide a link to the Creative Commons license, and indicate if changes were made.

\section{References}

Aitken A (1995) 14-3-3 proteins on the MAP. Trends Biochem Sci 20(3): 95-97

Ali GM, Komatsu S (2006) Proteomic analysis of rice leaf sheath during drought stress. J Proteome Res 5(2):396-403

Amme S, Matros A, Schlesier B, Mock HP (2006) Proteome analysis of cold stress response in Arabidopsis thaliana using DIGE-technology. J Exp Bot 57(7):1537-1546

An D, Yang J, Zhang P (2012) Transcriptome profiling of low temperature treated cassava apical shoots showed dynamic responses of tropical plant to cold stress. BMC Gen 13:64

An F, Fan J, Li J, Li QX, Li K, Zhu W, Wen F, Luiz JCBC, Chen S (2014) Comparison of leaf proteomes of cassava (Manihot esculenta Crantz) cultivar NZ199 diploid and autotetraploid genotypes. PLOS ONE 9(4):e85991

Aon MA, Cortassa S, Gomez Casati DF, Iglesias AA (2000) Effects of stress on cellular infrastructure and metabolic organization in plant cells. Int Rev Cytol 194:239-273

Balbuena TS, Salas JJ, Martínez-Force E, Garces R, Thelen JJ (2011) Proteome analysis of cold acclimation in sunflower. J Proteome Res 10(5):2330-2346

Bates LS, Waldren RP, Teare ID (1973) Rapid determination of free proline for water-stress studies. J Plant Soil 39(1):205-207

Batista de Souza CR, dos Reis SP, Carvalho LJCB (2015) An overview of protein identification studies in cassava. Curr Protein Pept Sci 16: 219-227

Beaucham C, Fridovic I (1971) Superoxide dismutase: improved assays and an assay applicable to acrylamide gels. Anal Biochem 44(1): 276-287

Boston RS, Viitanen PV, Vierling E (1996) Molecular chaperones and protein folding in plants. Plant Mol Biol 32(1-2):191-222

Bozhkov PV, Suarez MF, Filonova LH, Daniel G, Zamyatnin AA Jr, Rodriguez-Nieto S, Zhivotovsky B, Smertenko A (2005) Cysteine protease mcII-Pa executes programmed cell death during plant embryogenesis. Proc Natl Acad Sci U S A 102(40):14463-14468

Camoni L, Harper JF, Palmgren MG (1998) 14-3-3 proteins activate a plant calcium-dependent protein kinase (CDPK). FEBS Lett 430(3): 381-384

Cao WH, Liu J, He XJ, Mu RL, Zhou HL, Chen SY, Zhang JS (2007) Modulation of ethylene responses affects plant salt-stress responses. Plant Physiol 143(2):707-719

Carvalho LJ, Lippolis J, Chen S, Batista de Souza CR, Vieira EA, Anderson JV (2012) Characterization of carotenoid-protein complexes and gene expression analysis associated with carotenoid sequestration in pigmented cassava (Manihot Esculenta Crantz) storage root. Open Biochem J 6:116-130

Cavalcanti FR, Lima JPMS, Ferreira-Silva SL, Viégas RA, Silveira JAG (2007) Roots and leaves display contrasting oxidative response during salt stress and recovery in cowpea. J Plant Physiol 164:591-600

Chen SB, Heuer B (2013) Effect of genotype and exogenous application of glycinebetaine on antioxidant enzyme activity in native gels of $7-$ day-old salt-stressed tomato (Solanum lycopersicum) seedlings. Scientia Horticulturae 162:106-116
Chen S, Gollop N, Heuer B (2009) Proteomic analysis of salt-stressed tomato (Solanum lycposersicum) seedlings: effect of genotype and exogenous application of glycinebetaine. J Exp Bot 60(7):20052019

Chinnusamy V, Zhu JH, Zhu JK (2007) Cold stress regulation of gene expression in plants. Trends Plant Sci 12:444-451

Cui S, Huang F, Wang J, Ma X, Cheng Y, Liu J (2005) A proteomic analysis of cold stress responses in rice seedlings. Proteomics 5(12):3162-3172

Dhindsa RS, Plumbdhindsa P, Thorpe TA (1981) Leaf senescence: correlated with increased levels of membrane permeability and lipid peroxidation, and decreased levels of superoxide dismutase and catalase. J Exp Bot 32:93-101

Dietz KJ, Horling F, König J, Baier M (2002) The function of the chloroplast 2-cysteine peroxiredoxin in peroxide detoxification and its regulation. J Exp Bot 53(372):1321-1329

Dumont E, Bahrman N, Goulas E, Valot B, Sellier H, Hilbert JL, Vuylsteker C, Lejeune-Hénaut I, Delbreil B (2011) A proteomic approach to decipher chilling response from cold acclimation in pea (Pisum sativum L.). Plant Sci 180(1):86-98

Edwards R, Dixon DP, Walbot V (2000) Plant glutathione S-transferases: enzymes with multiple functions in sickness and in health. Trends Plant Sci 5(5):193-198

Ehlert B, Hincha DK (2008) Chlorophyll fluorescence imaging accurately quantifies freezing damage and cold acclimation responses in Arabidopsis leaves. Plant Methods 4(1):12

Fanucchi F, Alpi E, Olivieri S, Cannistraci CV, Bachi A, Alpi A, Alession M (2012) Acclimation increases freezing stress response of Arabidopsis thaliana at proteome level. Biochim Biophys Acta 1824(6):813-825

Ferl RJ (2004) 14-3-3 proteins: regulation of signal-induced events. Physiol Plant 120(2):173-178

Folgado R, Panis B, Sergeant K, Renaut J, Swennen R, Hausman JF (2013) Differential protein expression in response to abiotic stress in two potato species: Solanum commersonii Dun and Solanum tuberosum L. Int J Mol Sci 14(3):4912-4933

Gazanchian A, Hajheidari M, Sima NK, Salekdeh GH (2007) Proteome response of Elymus elongatum to severe water stress and recovery. J Exp Bot 58(2):291-300

Gilmour SJ, Zarka DG, Stockinger EJ, Salazar MP, Houghton JM, Thomashow MF (1998) Low temperature regulation of the Arabidopsis CBF family of AP2 transcriptional activators as an early step in cold-induced COR gene expression. Plant J 16(4): 433-442

Gleeson D, Lelu-Walter MA, Parkinson M (2005) Overproduction of proline in transgenic hybrid larch (Larix $\times$ leptoeuropaea (Dengler)) cultures renders them tolerant to cold, salt and frost. Mol Breed 15(1):21-29

Grimaud F, Renaut J, Dumont E, Sergeant K, Lucau-Danila A, Blervacq AS, Sellier H, Bahrman N, Lejeune-Hénaut I, Delbreil B, Goulas E (2013) Exploring chloroplastic changes related to chilling and freezing tolerance during cold acclimation of pea (Pisum sativum L.). J Proteomics 80:145-159

Gu X, Gao Z, Zhuang W, Qiao Y, Wang X, Mi L, Zhang Z, Lin Z (2013) Comparative proteomic analysis of $r d 29 A: R d r e B 1 B I$ transgenic and non-transgenic strawberries exposed to low temperature. J Plant Physiol 170(7):696-706

Haghjou MM, Shariati M, Smirnoff N (2009) The effect of acute high light and low temperature stresses on the ascorbate-glutathione cycle and superoxide dismutase activity in two Dunaliella salina strains. Physiol Plant 135(3):272-280

Hajduch M, Hearne LB, Miernyk JA, Casteel JE, Joshi T, Agrawal GK, Song Z, Zhou M, Xu D, Thelen JJ (2010) Systems analysis of seed filling in Arabidopsis: using general linear modeling to assess concordance of transcript and protein expression. Plant Physiol 152(4): 2078-2087 
Hajheidari M, Abdollahian-Noghabi M, Askari H, Heidari M, Sadeghian SY, Ober ES, Salekdeh GH (2005) Proteome analysis of sugar beet leaves under drought stress. Proteomics 5(4):950-960

Hajheidari M, Eivazi A, Buchanan BB, Wong JH, Majidi I, Salekdeh GH (2007) Proteomics uncovers a role for redox in drought tolerance in wheat. J Proteome Res 6(4):1451-1460

Hare PD, Cress WA, van Staden J (1998) Dissecting the roles of osmolyte accumulation during stress. Plant Cell Environ 21(6):535-553

Hashimoto M, Komatsu S (2007) Proteomic analysis of rice s during cold stress. Proteomics 7(8):1293-1302

Hodgson RAJ, Raison JK (1991) Lipid-peroxidation and superoxidedismutase activity in relation to photoinhibition induced by chilling in moderate light. Planta 185(2):215-219

Hu Y, Jia W, Wang J, Zhang Y, Yang L, Lin Z (2005) Transgenic tall fescue containing the Agrobacterium tumefaciens ipt gene shows enhanced cold tolerance. Plant Cell Rep 23(10-11):705-709

Huang L, Ye Z, Bell RW, Dell B (2005) Boron nutrition and chilling tolerance of warm climate crop species. Ann Bot 96:755-767

Ideker T, Thorsson V, Ranish JA, Christmas R, Buhler J, Eng JK, Bumgarner R, Goodlett DR, Aebersold R, Hood L (2001) Integrated genomic and proteomic analyses of a systematically perturbed metabolic network. Science 292(5518):929-934

Kjellsen TD, Shiryaeva L, Schröder WP, Strimbeck GR (2010) Proteomics of extreme freezing tolerance in Siberian spruce (Picea obovata). J Proteomics 73(5):965-975

Koehler G, Wilson RC, Goodpaster JV, Sonsteby A, Lai X, Witzmann FA, You JS, Rohloff J, Randall SK, Alsheikh M (2012) Proteomic study of low-temperature responses in strawberry cultivars (Fragaria $\times$ ananassa) that differ in cold tolerance. Plant Physiol 159(4):1787-1805

Lebot V (2008) Tropical root and tuber crops: cassava, sweet potato, yams and aroids. CABI. pp434

Lehesranta SJ, Davies HV, Shepherd LV, Nunan N, Mcnicol JW, Auriola S, Koistinen KM, Suomalainen S, Kokko HI, Kärenlampi SO (2005) Comparison of tuber proteome of potato varieties landraces, and genetically modified lines. Plant Physiol 138(3):1690-1699

Li K, Zhu W, Zeng K, Zhang Z, Ye J, Ou W, Rehman S, Heuer B, Chen S (2010) Proteome characterization of cassava (Manihot esculenta Crantz) somatic embryos, plantlets and tuberous roots. Proteome Sci 8:10

Li X, Cheng XX, Liu J, Zeng HM, Han LB, Tang W (2011) Heterologous expression of the Arabidopsis DREB1A/CBF3 gene enhances drought and freezing tolerance in transgenic Lolium perenne plants. Plant Biotechnol Rep 5(1):61-69

Li B, Zhang C, Cao B, Qin G, Wang W, Tian S (2012) Brassinolide enhances cold stress tolerance of fruit by regulating plasma membrane proteins and lipids. Amino Acids 43(6):2469-2480

Liu J, Zheng Q, Ma Q, Gadidasu KK, Zhang P (2011) Cassava genetic transformation and its application in breeding. J Integr Plant Biol 53(7):552-569

Liu XG, Xu H, Zhang JY, Liang GW, Liu YT, Guo AG (2012) Effect of low temperature on chlorophyll biosynthesis in albinism line of wheat (Triticum aestivum) FA85. Physiol Plant 145(3):384-394

Lyons JM (1973) Chilling injury in plants. Ann Rev Plant Physiol 24: 445-466

Mathur J, Spielhofer P, Kost B, Chua N (1999) The actin cytoskeleton is required to elaborate and maintain spatial patterning during trichome cell morphogenesis in Arabidopsis thaliana. Development 126(24): $5559-5568$

Mitprasat M, Roytrakul S, Jiemsup S, Boonseng O, Yokthongwattana K (2011) Leaf proteomic analysis in cassava (Manihot esculenta, Crantz) during plant development, from planting of stem cutting to storage root formation. Planta 233:1209-1221

Moon BY, Higashi S, Gombos Z, Murata N (1995) Unsaturation of the membrane lipids of chloroplasts stabilizes the photosynthetic machinery against low-temperature photoinhibition in transgenic tobacco plants. Proc Natl Acad Sci U S A 92(14):6219-6223
Nanjo T, Kobayashi M, Yoshiba Y, Kakubari Y, Yamaguchi-Shinozaki K, Shinozaki K (1999) Antisense suppression of proline degradation improves tolerance to freezing and salinity in Arabidopsis thaliana. FEBS Lett 461(3):205-210

Neilson KA, Mariani M, Haynes PA (2011) Quantitative proteomic analysis of cold-responsive proteins in rice. Proteomics 11(9):16971706

Neta-Sharir I, Isaacson T, Lurie S, Weiss D (2005) Dual role for tomato heat shock protein 21: protecting photosystem II from oxidative stress and promoting color changes during fruit maturation. Plant Cell 17(6):1829-1838

Orvar BL, Sangwan V, Omann F, Dhindsa RS (2000) Early steps in cold sensing by plant cells: the role of actin cytoskeleton and membrane fluidity. Plant J 23(6):785-794

Owiti J, Grossmann J, Gehrig P, Dessimoz C, Laloi C, Hansen MB, Gruissem W, Vanderschuren H (2011) iTRAQ-based analysis of changes in the cassava root proteome reveals pathways associated with post-harvest physiological deterioration. Plant J 67:145-156

Oxborough K (2004) Imaging of chlorophyll a fluorescence: theoretical and practical aspects of an emerging technique for the monitoring of photosynthetic performance. J Exp Bot 55(400):1195-1205

Parker R, Flowers TJ, Moore AL, Harpham NV (2006) An accurate and reproducible method for proteome profiling of the effects of salt stress in the rice leaf lamina. J Exp Bot 57(5):1109-1118

Porra RJ, Thompson WA, Kriedmann PE (1989) Determination of accurate extinction coefficients and simultaneous equations for assaying chlorophylls a and b extracted with four different solvents: verification of the concentration of chlorophyll standards by atomic absorption spectroscopy. Biochim Biophys Acta 975(3):384-394

Quintanilla-Guerrero F, Duarte-Vázquez MA, García-Almendarez BE, Tinoco R, Vazquez-Duhalt R, Regalado C (2008) Polyethylene glycol improves phenol removal by immobilized turnip peroxidase. Bioresource Technol 99(18):8605-8611

Rabbani MA, Maruyama K, Abe H, Khan MA, Katsura K, Ito Y, Yoshiwara K, Seki M, Shinozaki K, Yamaguchi-Shinozaki K (2003) Monitoring expression profiles of rice (Oryza sativa L.) genes under cold, drought and high salinity stress, and ABA application using both cDNA microarray and RNA gel blot analyses. Plant Physiol 133(4):1755-1767

Raimbault AK, Marie-Alphonsine PA, Horry JP, Francois-Haugrin M, Romuald K, Soler A (2011) Polyphenol oxidase and peroxidase expression in four pineapple varieties (Ananas comosus L.) after a chilling injury. J Agric Food Chem 59(1):342-348

Rey P, Cuiné S, Eymery F, Garin J, Court M, Jacquot JP, Rouhier N, Broin M (2005) Analysis of the protein targeted by CDSP32, a plastidic thioredoxin participating in oxidative stress responses. Plant J 41(1):31-42

Rinalducci S, Egidi MG, Karimzadeh G, Jazii FR, Zolla L (2012) Proteomic analysis of a spring wheat cultivar in response to prolonged cold stress. Electrophoresis 32(14):1807-1818

Rizza F, Pagani D, Stanca A, Cattivelli L (2001) Use of chlorophyll fluorescence to evaluate the cold acclimation and freezing tolerance of winter and spring oats. Plant Breed 120(5):389-96

Roberts MR (2003) 14-3-3 proteins find new partners in plant cell signaling. Trends Plant Sci 8(5):218-223

Sairam RK, Srivastava GC, Agarwal S, Meena RC (2005) Differences in antioxidant activity in response to salinity stress in tolerant and susceptible wheat genotypes. Biologia Plantarum 49:85-91

Sanchez-Bel P, Egea I, Sanchez-Ballesta MT, Sevillano L, Del Carmen BM, Flores FB (2012) Proteome changes in tomato fruits prior to visible symptoms of chilling injury are linked to defensive mechanisms, uncoupling of photosynthetic processes and protein degradation machinery. Plant Cell Physiol 53(2):470-484

Sangwan V, Foulds I, Singh J, Dhindsa RS (2001) Cold-activation of Brassica napus BN115 promoter is mediated by structural changes 
in membranes and cytoskeleton, and requires $\mathrm{Ca}^{2+}$ influx. Plant $\mathrm{J}$ 27(1):1-12

Sehnke PC, DeLille JM, Ferl RJ (2002) Consummating signal transduction: the role of 14-3-3 proteins in the completion of signal-induced transitions in protein activity. The Plant Cell S339-S354

Sergeant K, Renaut J (2010) Plant biotic stress and proteomics. Curr Proteomics 7(4):275-297

Sheffield J, Taylor N, Fauquet C, Chen S (2006) The cassava (Manihot esculenta Crantz) root proteome: protein identification and differential expression. Proteomics 6(5):1588-1598

Swigonska S, Weidner S (2013) Proteomic analysis of response to longterm continuous stress in roots of germinating soybean seeds. J Plant Physiol 170(5):470-479

Thomashow MF (1998) Role of cold-responsive genes in plant freezing tolerance. Plant Physiol 118(1):1-8

Timperio AM, Egidi MG, Zolla L (2008) Proteomics applied on plant abiotic stresses: role of heat shock proteins (HSP). J Proteomics 71(4):391-411

Torabi S, Wissuwa M, Heidari M, Naghavi MR, Cilany K, Hajirezaei MR, Omidi M, Yazdi-Samadi B, Ismail AM, Salekdeh GH (2009) A comparative proteome approach to decipher the mechanism of rice adaptation to phosphorous deficiency. Proteomics 9(1):159-170

Van Breusegem F, Slooten L, Stassart JM, Botterman J, Moens T, Van Montagu M, Inze D (1999) Effects of overproduction of tobacco MnSOD in maize chloroplasts on foliar tolerance to cold and oxidative stress. J Exp Bot 50(300):71-78

Vaultier MN, Cantrel C, Vergnolle C, Justin AM, Demandre C, Benhassaine-Kesri G, Cicek D, Zachowski A, Ruelland E (2006) Desaturase mutants reveal that membrane rigidification acts as a cold perception mechanism upstream of the diacylglycerol kinase pathway in Arabidopsis cells. FEBS Lett 580(17):4218-4223

Vercammen D, van de Cotte B, De Jaeger G, Eeckhout D, Casteels P, Vandepoele K, Vandenberghe I, Van Beeumen J, Inzé D, Van Breusegem F (2004) Type II metacaspases Atmc4 and Atmc9 of Arabidopsis thaliana cleave substrates after arginine and lysine. J Biol Chem 279(44):45329-36

Vergnolle C, Vaultier MN, Taconnat L, Renou JP, Kader JC, Zachowski A, Ruelland E (2005) The cold-induced early activation of phospholipases $\mathrm{C}$ and $\mathrm{D}$ pathways determines the response of two distinct clusters of genes in Arabidopsis suspension cell. Plant Physiol 139(3):1217-1233
Wang X, Yang P, Gao Q, Liu X, Kuang T, Shen S, He Y (2008) Proteomic analysis of the response to high-salinity stress in Physcomitrella patens. Planta 228(1):167-177

Wang X, Yang P, Zhang X, Xu Y, Kuang T, Shen S, He Y (2009) Proteomic analysis of the cold stress response in the moss, Physcomitrella patens. Proteomics 9:1-10

Wang W, Feng B, Xiao J, Xia Z, Zhou X, Li P, Zhang W, Wang Y, Møller BL, Zhang P, Luo MC, Xiao G, Liu J, Yang J, Chen S, Rabinowicz PD, Chen X, Zhang HB, Ceballos H, lou Q, Zou M, Carvalho LJ, Zeng C, Xia J, Sun S, Fu Y, Wang H, Lu C, Ruan M, Zhou S, Wu Z, Liu H, Kannangara RM, Jørgensen K, Neale RL, Bonde M, Heinz N, Zhu W, Wang S, Zhang Y, Pan K, Wen M, Ma PA, Li Z, Hu M, Liao W, Hu W, Zhang S, Pei J, Guo A, Guo J, Zhang J, Zhang Z, Ye J, Ou W, Ma Y, Liu X, Tallon LJ, Galens K, Ott S, Huang J, Xue J, An F, Yao Q, Lu X, Fregene M, López-Lavalle LA, Wu J, You FM, Chen M, Hu S, Wu G, Zhong S, Ling P, Chen Y, Wang Q, Liu G, Liu B, Li K, Peng M (2014) Cassava genome from a wild ancestor to cultivated varieties. Nat Commun 5:5110

Wettstein D, Simon G, Kannangara GC (1995) Chlorophyll biosynthesis. Plant Cell 7:1039-1057

Xu J, Duan X, Yang J, Beeching JR, Zhang P (2013) Coupled expression of $\mathrm{Cu} / \mathrm{Zn}$-superoxide dismutase and catalase in cassava improves tolerance against cold and drought stresses. Plant Signal Behav 8(6):e24525

Xu J, Yang J, Duan X, Zhang P, Jiang Y (2014) Increased expression of native cytosolic $\mathrm{Cu} / \mathrm{Zn}$ superoxide dismutase and ascorbate peroxidase improves tolerance to oxidative and chilling stresses in cassava (Manihot esculenta Crantz). BMC Plant Biol 14:208

Zhao P, Liu P, Shao J, Li C, Wang B, Guo X, Yan B, Xia Y, Peng M (2015) Analysis of different strategies adapted by two cassava cultivars in response to drought stress: ensuring survival or continuing growth. J Exp Bot 66:1477-88

Zhou CY, Yang CD, Zhan L (2012a) Effects of low temperature stress on physiological and biochemical characteristics of Podocarpus nagi. Agric Sci Technol 13(3):533-536

Zhou Y, Zhang D, Pan J, Kong X, Liu Y, Sun L, Wang L, Li D (2012b) Overexpression of a multiple stress-responsive gene, ZmMPK4, enhances tolerance to low temperature in transgenic tobacco. Plant Physiol Biochem 58:174-181

Zhuo C, Wang T, Lu S, Zhao Y, Li X, Guo Z (2013) A cold responsive galactinol synthase gene from Medicago falcata (MfGolSl) is induced by myo-inositol and confers multiple tolerances to abiotic stresses. Physiol Plant 149(1):67-78 